\title{
Industrial Production and Capacity Utilization: 1998 Annual Revision
}

Charles Gilbert and Richard Raddock, of the Board's Division of Research and Statistics, prepared this article. Robert Ritterbeck provided research assistance.

In late 1998, the Federal Reserve published revised indexes of industrial production (IP) and the related measures of capacity and utilization for the period January 1992 through October 1998. For the third quarter of 1998, the revision placed the production index at 131.6 percent of output in 1992, compared with 128.2 percent reported previously, and the capacity index at 161.5 percent of output in 1992, compared with 158.1 percent reported previously. ${ }^{1}$ As a result, the rate of industrial capacity utilization - the ratio of production to capacity-for that quarter was revised up 0.3 percentage point, to 81.5 percent. (Summary data for total industry and manufacturing are shown in appendix tables A.1 and A.2.)

The updated measures reflect both the incorporation of newly available, more comprehensive source data typical of annual revisions and, for some series, the introduction of modifications in the methods for compiling the series. The new source data, which are principally derived from the 1996 Annual Survey of Manufactures and the 1997 Survey of Plant Capacity, affect data for 1995 and thereafter. The modified methods affect data for 1992 onward.

Growth in the output and capacity of hightechnology industries is now estimated to have been more rapid than previously shown. Outside of the high-technology industries, revisions to the output indexes for individual industries were largely offsetting and had little net effect on the overall IP index through 1997 (chart 1).

\footnotetext{
Note. Other contributors to the revision and this article include the following: Ana Aizcorbe, William Cleveland, Carol Corrado, Maura Doyle, Norman Morin, and Dixon Tranum.

1. The revisions to the industrial production data for August through October 1998 and the new data for November from the Board's G.17 statistical release on "Industrial Production and Capacity Utilization," issued on December 16, 1998, have been incorporated in all the statistics and tables presented in this article.
}

\begin{abstract}
REVISIONS TO PRODUCTION, CAPACITY, AND UTILIZATION
\end{abstract}

\section{Production}

The revised increases in the total IP index are about the same as those shown previously for 1993 and 1994 but are faster for 1995-98 (table A.3). The revised annual rate of growth has averaged 4.5 percent since 1994, 0.8 percentage point higher than previously shown; the upward revision for 1996 forward was close to 1 percentage point per year. The index shows the same pattern of output growth since 1992: No quarter shows a decrease in output, but gains were slower between the second quarter of 1995 and the first quarter of 1996, and again beginning with the first quarter of 1998 . The slowing in the latter period reflects the effects of the economic turmoil in Asia.

\section{By Market Groups}

Among major market groups, the expansion of output was pervasive and substantial in 1996 and 1997, with strength concentrated in business equipment, durable consumer goods, and related materials; only the production of defense and space equipment declined in these years. The production of nondurable consumer products advanced relatively slowly; solid growth in the consumer chemical products industry was offset by declines in apparel production for 1995 through the present.

In 1998, growth was slower in the production of consumer goods, business equipment other than information processing equipment, and both durable and nondurable materials. The output of information processing and related equipment continued to increase strongly, and the output of construction supplies accelerated after having risen slowly in 1997. The output of energy products and materials also picked up, on balance, a move reflecting the unusual weather patterns since last fall. The output of defense and space equipment edged up after having declined substantially for most of this decade. 
1. Industrial production, capacity, and utilization

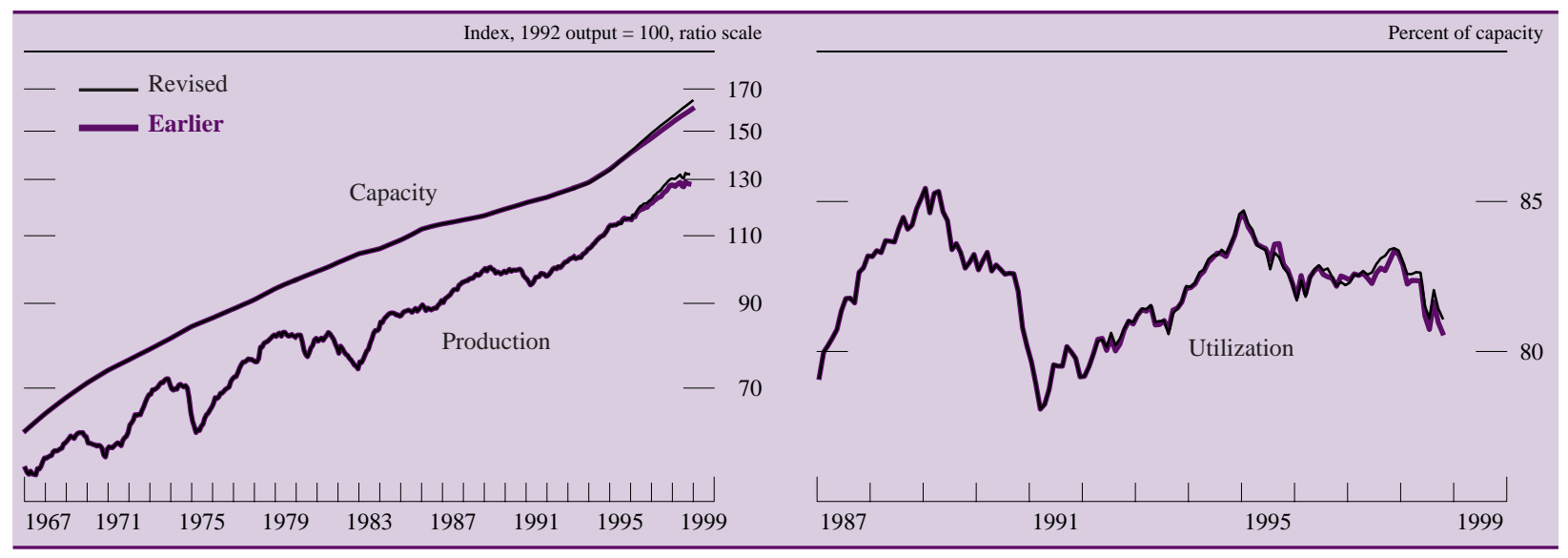

Note. The production indexes and utilization rates are seasonally adjusted. All the revised measures extend through November 1998; the earlier measures extend through October 1998.

\section{By Industry Groups}

The revised figures continue to show that during the past two years growth among the broad industry groups was concentrated in durable manufacturing, which advanced 11.1 percent in 1997 before easing to a 4.2 percent annual rate in the first three quarters of 1998 . The relatively rapid expansion in this sector has been supported over the years by sustained rapid increases in the output of computers, semiconductors and related electronic components, and communications equipment. According to the revised index, the annual rate of growth of production in these hightechnology industries averaged nearly 40 percent for 1994 through 1997, substantially higher than previously shown (table A.4). The growth of output of other manufacturing industries, which was revised little on balance for the 1994-97 period, advanced 3.0 percent over the four quarters of 1996 and 4.3 percent over 1997 before edging down in 1998. In 1998, the economic troubles in Asia have, either through more imports or fewer exports, reduced the domestic production of iron and steel, semiconductors, some chemicals, and other internationally traded goods. However, the revised series for civilian aircraft shows stronger growth in the first half of 1998 than shown previously.

\section{Capacity}

The revised measures of capacity and utilization reflect the new IP indexes, updated estimates of manufacturing capital input, new information on physical capacity and utilization for selected industries provided mainly by trade associations, and pre- liminary results of the 1997 Survey of Plant Capacity conducted by the Bureau of the Census, which yielded utilization rates for manufacturing industries for the fourth quarter of 1997.

As was the case with the IP index, the rate of growth of manufacturing capacity was revised upward for 1995 forward (table A.5). The revised figures show that the annual rate of growth jumped to 6.0 percent in 1995 and 6.4 percent in 1996. It has slowed a bit in the past two years; 1998 growth is estimated to have been 5.6 percent. The rapid growth and upward revisions were again concentrated in durable manufacturing, especially in the high-technology industries. The capacity increase in these industries peaked at 46.3 percent in 1996 and then decelerated to 34.8 percent by 1998 . In contrast, capacity growth in the rest of manufacturing was approximately 3 percent in 1995 and 1996 and then declined to an estimated 2.6 percent by 1998 .

Capacity expansion in mining and utilities was considerably slower. In particular, the North American Electric Reliability Council reduced its estimate of generating capacity for the winter of 1997 and projected increases in capacity short of probable increases in demand. Moreover, the drop in world demand for crude oil and its low price have led to a sharp drop in work in domestic oil fields.

\section{Capacity Utilization}

For 1997 and 1998, the upward revisions to manufacturing capacity were relatively smaller than the revisions to output; consequently, the rate of manufacturing capacity utilization was revised up 0.3 percentage point for the fourth quarter of 1997 and 0.6 percent- 
age point for the third quarter of 1998 (table A.6). The largest upward revision of utilization was for the transportation equipment industry. Utilization in manufacturing in the third quarter of 1998 was 80.2 percent, a level that is 0.9 percentage point less than the 1967-97 average, as the rates in both primary- and advanced-processing industries fell more than 2 percentage points over the first three quarters of 1998. In contrast to the general easing in manufacturing utilization rates, the rate rose further for petroleum products, to 96.5 percent. The low price of crude oil pushed refining activity toward capacity limits.

The capacity utilization rate for mining for the third quarter of 1998 was revised down 2.5 percentage points, leaving it more than a percentage point below its long-term average. Although the rate for gas utilities also was revised down, to a belowaverage level, the rate for electric utilities was revised upward to 97.7 percent, its highest level since 1970. Strong summer demand for air conditioning due to high temperatures forced some utilities to limit their supply of electricity to industrial companies.

\section{TECHNICAL ASPECTS OF THE ANNUAL REVISION}

The revision incorporates the updating of the comprehensive annual data and of the monthly source data used in the estimation of production, capacity, and utilization. More up-to-date results were obtained from the 1996 Annual Survey of Manufactures, the 1997 Survey of Plant Capacity, other annual industry reports, recent information on prices, and revised monthly source data on physical products and on labor and electricity inputs. ${ }^{2}$ Productivity relationships were revised on the basis of the differences between the new annual and monthly data and applied to the individual monthly source data to determine the final individual production indexes. Along with the individual production series and seasonal factors, the annual value-added weights used in aggregating the indexes to market and industry groups were also updated.

\section{Changes to Individual Production Series}

The industry and market structures of the index of industrial production now comprise 267 individual

2. Information about the sources of monthly data used to calculate the indexes can be found in "Table 1: Industry structure of industrial production: Classification, value-added weights, and description of series" on the Board's World Wide Web site (http:// www.federalreserve.gov/releases/g17/About.htm). series, up from 264 at the time of the previous annual revision. Individual series were changed for electronic components, coal, aircraft, and lawn and garden equipment.

The electronic components industry, SIC 367, was previously covered by two indexes, one for TV tubes and the second for semiconductors and other components. Now, four new indexes cover electronic components other than TV tubes: (1) semiconductors and related devices, SIC 3674; (2) printed circuit boards, SIC 3672; (3) other electronic components, SIC 3675-8 and part of 3679; and (4) printed circuit assemblies and loaded boards, part of SIC 3679. Development of the estimates of production of semiconductors and related devices is discussed below; the other three series are derived from monthly Bureau of Labor Statistics data on worker hours and productivity trends determined by annual data. The four series appear within the industry structure of the IP index in the subgroup electronic components, SIC 367; and within the market structure in equipment parts, a subgroup within durable goods materials, as shown in the following table:

Semiconductors and Related Electronic Components within the Market Structure

\begin{tabular}{|c|c|}
\hline Series & $\begin{array}{c}1997 \\
\text { value-added } \\
\text { share }\end{array}$ \\
\hline 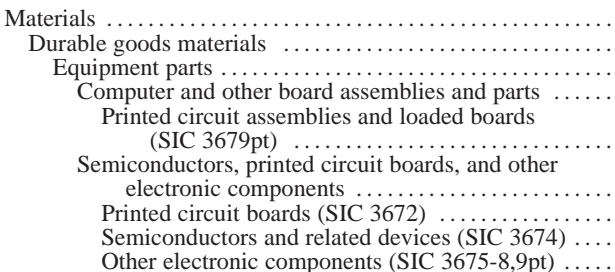 & $\begin{array}{r}40.2 \\
24.0 \\
9.2 \\
.9 \\
.5 \\
.5 \\
3.7 \\
.3 \\
2.8 \\
.6\end{array}$ \\
\hline
\end{tabular}

The new production measure for semiconductors and related devices (SIC 3674) attempts to capture advances in the capability of these devices as well as changes in volumes produced by aggregating detailed information on physical quantities and average unit values for about 300 distinct devices. ${ }^{3}$ A chained Fisher quantity index of semiconductor output is derived by dividing an estimate of nominal domestic production by a chained Fisher price index.

Nominal domestic production is estimated using monthly data from the World Semiconductor Trade

3. The data for the individual devices are aggregated using Fisher aggregation methods. See Carol Corrado, Charles Gilbert, and Richard Raddock, "Industrial Production and Capacity Utilization: Historical Revision and Recent Developments," Federal Reserve Bulletin, vol. 83 (February 1997), pp. 67-92, for a general description of the methodology. 
Statistics monthly (WSTS) issued by the Semiconductor Industries Association and estimates of the U.S. share of world shipments based on data from the Census Bureau's annual Current Industrial Reports for semiconductors.

Data on physical quantities and average unit values for the different semiconductor devices are obtained from several sources and used to construct price indexes for about a dozen categories of chips. Data on metal oxide semiconductor (MOS) microprocessors (MPUs) come from MicroDesign Resources; data on MOS memories and selected MOS logic chips other than MPUs come from Dataquest; and data on other devices come from the WSTS.

The price indexes computed from these data for MOS memories and MOS MPUs are quantitatively very similar to those published by the Bureau of Economic Analysis for the period 1992 through 1996, and to the new producer price indexes (PPI) published by the Bureau of Labor Statistics since January 1997. ${ }^{4}$ In contrast, the price indexes that are used in the industrial production system for non-MOS devices and MOS logic chips other than MPUs show steeper price declines than the corresponding PPI measures.

Some minor products of SIC 3674 are not included in the semiconductor indicator described above. The nominal gross output data from the Annual Survey of Manufactures (ASM) for the industry include all of the products made by the industry, so the price deflator constructed above is augmented by producer price indexes for the secondary products of the industry when computing the deflator for the nominal gross output data for the industry. The final industrial production estimate for semiconductors and related devices includes a correction to align the monthly output index to the deflated gross output data for the industry.

Changes to individual series other than those in the electronic components subgroup include revised IP series for coal, completed commercial aircraft, and lawn and garden equipment. The coal series had been based directly on tonnage production. However, the quality of U.S. coal varies by region. ${ }^{5}$ For example, a

4. See Bruce T. Grimm, "Price Indexes for Selected Semiconductors, 1974-96," Survey of Current Business (U.S. Department of Commerce, Bureau of Economic Analysis, February 1998); and Mike Holdway, "Changes in the PPI for Semiconductors Indexes," Producer Price Indexes: PPI Detail Report (U.S. Department of Labor, Bureau of Labor Statistics, January 1997).

5. See A. Denny Ellerman, Thomas M. Stoker, and Ernst R. Berndt, "Sources of Productivity Growth in the American Coal Industry, 1972-95" (paper prepared for a meeting of the Conference on Research on Income and Wealth, New Directions in Productivity Analysis, Washington, D.C., March 1998). ton of coal from Appalachia provides more heat, expressed in British thermal units (Btu), than a ton of lignite coal from North Dakota, Texas, or Louisiana. The growth in coal production over the past decade or so has been concentrated in subbituminous coal, which is extracted by surface mining at low cost in Wyoming and western Montana and is relatively low in Btu content. Therefore, the revised index of coal production weights the tonnage produced in a region by the Btu content typical of a ton of coal mined in that region.

Completed aircraft, SIC 3721, includes both commercial and military aircraft. The benchmark annual levels for this industry are gross output levels for the industry, derived from data from the ASM and from price deflators from the Bureau of Economic Analysis. These benchmark levels are split into military and civilian components on the basis of more detailed ASM product shipments.

The goal of the revision for this industry was to make the IP indexes reflect actual aircraft operations. Previously the indexes were based on monthly production-worker hours and rested on productivity assumptions that were developed from historical trends. One of the difficulties with this approach was that the information on production-worker hours does

\section{Data Changes and Availability}

Data on production, capacity, and utilization are published monthly in the Board's G.17 statistical release "Industrial Production and Capacity Utilization." As described in the accompanying article, the data for 1992 and after have been revised. This revision marks the introduction of one new market group: semiconductors, printed circuit boards, and other electronic components.

Files containing all the historical data can be found on the Board's web site (http://www.federalreserve.gov) under "Statistics: Releases and historical data." For paid access to these files through the Department of Commerce's Economic Bulletin Board or web site, please call STAT-USA at 1-800-STAT-USA (1-202-482-1986).

Diskettes containing either historical data (through 1985) or more recent data (1986 to those most recently published in the G.17 statistical release) are available from Publications Services, Board of Governors of the Federal Reserve System, Washington, DC 20551 (202-452-3245).

A document with printed tables of the revised estimates of series shown in the G.17 release is available upon request to the Industrial Output Section, Mail Stop 82, Division of Research and Statistics, Board of Governors of the Federal Reserve System, Washington, DC 20551. 
not distinguish hours used in the production of commercial aircraft from hours used in the production of military aircraft. Under the new procedure, the production measure for commercial aircraft approximately equals a forward-looking ten-month moving average of actual or future planned completions (deliveries plus the change in stock) of commercial aircraft by Boeing Corporation. The final IP index is also constructed so that its monthly changes are positively correlated with the monthly changes in production-worker hours.

The estimates of military aircraft productivity were also improved, using annual information on planned production of military aircraft, including fighters, bombers, cargo planes, and AWACS planes, which were combined into an annual aggregate military aircraft production indicator using prices available on Department of Defense web sites. This indicator, combined with the estimate of commercial aircraft production, provides a good estimate of the overall production of complete aircraft through the current year.

Finally, a physical product series for lawn and garden equipment, SIC 3524, was developed using data for production of lawn and garden tractors, mowers, rotary tillers, and snow throwers from Stark's Component Ledger. The data represent output for the three-month period from the third month of a given calendar quarter through the second month of the following quarter. Through 1992, the monthly indicator for this series remains production-worker hours.

\section{Weights}

The IP index is an annually weighted Fisher index. ${ }^{6}$ In the revision, the annual value-added weights for the aggregation of the IP indexes and the capacity utilization rates, which are derived from annual estimates of industry value added, were updated and extrapolated (table A.7). Data from the Annual Survey of Manufactures, together with revenue and expense data reported by the Department of Energy and the American Gas Association, provided information on industry value added for manufacturing and utilities through 1996; the latest value-added data for mining came from the Census of Mineral Industries for 1992. The weights are expressed as unit value added. Generally, the unit-value-added measures track broad changes in corresponding producer

6. The aggregation procedures are described in Corrado, Gilbert, and Raddock, "Industrial Production and Capacity Utilization: Historical Revision and Recent Developments." prices. The weights required for aggregating IP in the most recent period are (1) estimated from available data on producer prices through the most recent year and (2) extrapolated for the following year, given the persistence of many relative price trends.

\section{Revised Monthly Data}

The monthly physical product data that are used to measure the monthly movements of many IP indexes have been updated to capture data that became available after the closing of the regular four-month reporting window. For many individual IP indexes, monthly data on production-worker hours or sales of electric power to industry groups, in kilowatt-hours, along with estimates of trends in output per worker hour or kilowatt-hour, are used to indicate the monthly change in output. This revision incorporates the Bureau of Labor Statistics benchmark of the employment data for March 1997. It also incorporates revised data on the sales of electricity to industries for 1992 onward. The monthly kilowatt-hour sales figures were benchmarked to data on the annual use of electric power reported in the Annual Survey of Manufactures through 1996. The incorporation of the new data resulted in an average upward revision in industrial use of electric power of 0.3 percentage point per year over the period 1994 through 1996 (table A.8). Seasonal factors for the electric power series were reestimated using data through May $1998 .^{7}$

This revision also introduced an improvement in the techniques for adjusting monthly electric power data for systematic influences of the weather. Data on electric power use by establishments in fifty threedigit SIC industries are used as monthly indicators for production in forty-two component IP series. Unusually warm or cool temperatures appear at times to have caused the use of electricity to rise or fall independently of its use in production. Staff research indicated that the usual seasonal adjustment techniques did not adequately capture the influence of the weather on electric power usage by thirteen industries, which are used to infer production for almost 16 percent of the IP index. The revised IP index estimates for these thirteen industries incorporate electric power use series with the effects of unseasonable weather removed; the procedure uses data on national heating and cooling degree days to model weather effects.

7. Seasonal factors for worker hours were based on data through October 1998; factors for the monthly physical product series were based on data through June or later in the summer. 


\section{Measurement of Capacity}

The revisions to capacity and utilization incorporate the revised production indexes, the preliminary results of the 1997 Survey of Plant Capacity, updated measures of 1997 and 1998 capacity in physical units for selected industries, and revised estimates of industry capital input. The 1997 Survey of Plant Capacity, which was conducted by the Bureau of the Census and partially funded by the Federal Reserve, returned to being conducted annually; from 1989 to 1996, results from the survey were received every two years.

The Survey of Plant Capacity is the Federal Reserve's source of utilization rates for most manufacturing industries. The preliminary results of the 1997 survey, along with revisions to the 1996 survey, suggested that trends in manufacturing utilization rates were roughly in line with those previously estimated by the Federal Reserve for those years. However, dividing the industrial production indexes for high-technology industries, which were generally revised substantially upward, by the Census utilization rates yielded a noticeable upward revision of capacity in those industries.

An estimate of capital input for an industry is typically the third major component, along with an IP index and a survey utilization rate, in the Federal Reserve's procedure for estimating capacity by industry (see box "Procedure for Estimating Capacity"). Revised BEA estimates of business investment and deflators by asset type through mid-1998 were incorporated with this revision. The effect of these new data on the overall manufacturing capital input measure was very small.

\section{Procedure for Estimating Capacity}

The Federal Reserve's procedure for constructing individual capacity indexes involves several steps. First preliminary, implied end-of-the-year indexes of capacity are calculated by dividing a production index by a utilization rate obtained from a survey for that end-of-year period. These ratios, like the indexes of industrial production, are expressed as percentages of 1992 production; they give the general level and trend of the capacity estimates. ${ }^{1}$

Once the preliminary implied capacity indexes are calculated, measures of physical capacity or of capital input are used to estimate and extrapolate the annual movements of the capacity indexes. For most manufacturing industries, physical measures of capacity are lacking; in these cases, the annual growth in the capacity estimates is related to the growth in an industry's capital input. The capital input measures are developed principally from investment data reported in the Annual Survey of Manufactures.

1. Each implied capacity index number is an estimate of a sustainable maximum level of output expressed as a percentage of actual output in 1992. Thus, if in the fourth quarter of 1992 the production index is 100 and a related utilization rate from a survey is 80 percent, then the implied capacity index is $100 / .8$, or 125 .

The capacity indexes capture the concept of sustainable practical capacity, which is defined as the greatest level of output that a plant can maintain within the framework of a realistic work schedule after taking account of normal downtime and assuming sufficient availability of inputs to operate the machinery and equipment in place. The questions asked in both the broad Census Bureau survey and the narrower surveys of selected industries are generally consistent with this definition of capacity. The concept itself generally conforms to that of a full-input point on a production function, with the qualification that capacity represents a realistically sustainable maximum, rather than some higher unsustainable short-term maximum. See Carol Corrado and Joe Mattey, "Capacity Utilization," Journal of Economic Perspectives, vol. 11 (Winter 1997), pp. 151-67.

In the absence of utilization rate information for an industry, which is the case for a few series in mining, trends through peaks in production are used to estimate capacity output for that industry. 


\section{APPENDIX A: SUMMARY TABLES BASED ON THE G.17 RELEASE, DECEMBER 16, 1998}

A.1. Revised data for industrial production, capacity, and utilization for total industry, 1987-98

Seasonally adjusted data except as noted

\begin{tabular}{|c|c|c|c|c|c|c|c|c|c|c|c|c|c|c|c|c|c|}
\hline \multirow{2}{*}{ Year } & \multirow{2}{*}{ Jan. } & \multirow{2}{*}{ Feb. } & \multirow{2}{*}{ Mar. } & \multirow{2}{*}{ Apr. } & \multirow{2}{*}{ May } & \multirow{2}{*}{ June } & \multirow{2}{*}{ July } & \multirow{2}{*}{ Aug. } & \multirow{2}{*}{ Sept. } & \multirow{2}{*}{ Oct. } & \multirow{2}{*}{ Nov. } & \multirow{2}{*}{ Dec. } & & $\mathrm{Qu}$ & irter & & \\
\hline & & & & & & & & & & & & & 1 & 2 & 3 & 4 & avg. ${ }^{1}$ \\
\hline & & & & & & & Industr & al produ & tion (pe & centage & hange) & & & & & & \\
\hline 1987 & -.6 & 1.2 & .4 & .4 & .4 & .9 & .6 & .1 & -.1 & 1.4 & .3 & 6 & 4.2 & 6.7 & 5.6 & 7.1 & 4.6 \\
\hline 1988 & .1 & .3 & .0 & 6 & .1 & .1 & .7 & .5 & -.4 & .3 & .8 & .5 & 3.2 & 3.1 & 3.9 & 3.6 & 4.5 \\
\hline 1989 & .6 & -.8 & .9 & .2 & -.6 & -.2 & -1.0 & .4 & -.2 & -.5 & .4 & .5 & 3.8 & .5 & -4.4 & -.1 & 1.8 \\
\hline 1990 & -.5 & .5 & .5 & -.6 & .4 & .0 & .0 & .2 & .1 & -.6 & -1.3 & -.6 & 2.0 & 6 & 1.0 & -5.8 & -.2 \\
\hline 1991 & -.5 & -.8 & -.9 & .3 & .8 & 1.2 & .1 & .1 & 1.0 & -.1 & -.1 & -.6 & -8.3 & 1.5 & 6.2 & 1.1 & -2.0 \\
\hline 1992 & .2 & .6 & .7 & .7 & .2 & -.1 & .8 & -.3 & .4 & .6 & .5 & .1 & 1.3 & 6.1 & 2.7 & 4.6 & 3.1 \\
\hline 1993 & .5 & .5 & .2 & .4 & -.5 & .2 & .2 & -.4 & 1.0 & .4 & .5 & .8 & 4.3 & 1.5 & 1.2 & 6.4 & 3.5 \\
\hline 1994 & .2 & .5 & .7 & .4 & .7 & .5 & .3 & .5 & .2 & .7 & .8 & 1.1 & 6.1 & 7.1 & 5.2 & 7.6 & 5.4 \\
\hline 1995 & .5 & -.1 & .2 & -.1 & .3 & 4 & -.3 & 1.1 & .3 & .0 & .2 & .0 & 6.3 & 1.3 & 3.5 & 3.0 & 4.9 \\
\hline 1996 & -.2 & 1.3 & -.2 & 1.2 & .9 & .7 & .2 & .5 & .1 & .1 & .6 & .3 & 2.8 & 9.6 & 5.5 & 3.5 & 4.5 \\
\hline 1997 & .5 & .7 & .4 & .6 & .3 & .5 & .7 & 6 & .5 & .6 & .5 & .3 & 6.6 & 6.0 & 7.2 & 6.6 & 6.0 \\
\hline 1998 & .0 & -.1 & .4 & .5 & .4 & -.9 & -.1 & 1.4 & -.4 & .2 & -.3 & & 1.6 & 2.8 & .9 & $\ldots$ & $\ldots$ \\
\hline & & & & & & & & idustria & product & on (inde & & & & & & & \\
\hline 1987 & 90.2 & 91.2 & 91.6 & 92.0 & 92.4 & 93.2 & 93.7 & 93.8 & 93.7 & 95.0 & 95.3 & 95.9 & 91.0 & 92.5 & 93.8 & 95.4 & 93.2 \\
\hline 1988 & 95.9 & 96.2 & 96.3 & 96.8 & 96.9 & 97.0 & 97.6 & 98.1 & 97.8 & 98.0 & 98.8 & 99.3 & 96.1 & 96.9 & 97.8 & 98.7 & 97.4 \\
\hline 1989 & 99.8 & 99.0 & 100.0 & 100.2 & 99.6 & 99.4 & 98.4 & 98.8 & 98.6 & 98.2 & 98.6 & 99.0 & 99.6 & 99.7 & 98.6 & 98.6 & 99.1 \\
\hline 1990 & 98.6 & 99.1 & 99.6 & 99.0 & 99.4 & 99.3 & 99.3 & 99.5 & 99.6 & 99.1 & 97.7 & 97.2 & 99.1 & 99.2 & 99.5 & 98.0 & 98.9 \\
\hline 1991 & 96.7 & 95.9 & 95.0 & 95.4 & 96.1 & 97.2 & 97.3 & 97.4 & 98.4 & 98.3 & 98.1 & 97.5 & 95.9 & 96.2 & 97.7 & 98.0 & 97.0 \\
\hline 1992 & 97.7 & 98.2 & 98.9 & 99.6 & 99.9 & 99.7 & 100.5 & 100.2 & 100.6 & 101.2 & 101.7 & 101.8 & 98.3 & 99.8 & 100.4 & 101.5 & 100.0 \\
\hline 1993 & 102.3 & 102.7 & 102.9 & 103.3 & 102.7 & 103.0 & 103.2 & 102.8 & 103.9 & 104.3 & 104.8 & 105.7 & 102.6 & 103.0 & 103.3 & 104.9 & 103.5 \\
\hline 1994 & 105.9 & 106.4 & 107.2 & 107.6 & 108.4 & 108.9 & 109.3 & 109.8 & 110.0 & 110.8 & 111.6 & 112.9 & 106.5 & 108.3 & 109.7 & 111.7 & 109.1 \\
\hline 1995 & 113.4 & 113.4 & 113.6 & 113.4 & 113.8 & 114.3 & 113.9 & 115.1 & 115.4 & 115.5 & 115.7 & 115.8 & 113.5 & 113.8 & 114.8 & 115.7 & 114.4 \\
\hline 1996 & 115.5 & 117.0 & 116.8 & 118.2 & 119.2 & 120.0 & 120.3 & 120.9 & 121.1 & 121.2 & 121.9 & 122.3 & 116.5 & 119.2 & 120.8 & 121.8 & 119.5 \\
\hline 1997 & 123.0 & 123.9 & 124.4 & 125.1 & 125.5 & 126.1 & 127.0 & 127.8 & 128.5 & 129.3 & 129.9 & 130.3 & 123.7 & 125.6 & 127.8 & 129.8 & 126.8 \\
\hline 1998 & 130.3 & 130.2 & 130.7 & 131.3 & 131.9 & 130.6 & 130.5 & 132.4 & 131.9 & 132.2 & 131.8 & $\ldots$ & 130.4 & 131.3 & 131.6 & $\ldots$ & $\ldots$ \\
\hline & & & & & & & & $\mathrm{Ca}$ & acity (in & dex) & & & & & & & \\
\hline 1987 & 114.0 & 114.1 & 114.2 & 114.3 & 114.4 & 114.5 & 114.6 & 114.7 & 114.9 & 115.0 & 115.1 & 115.2 & 114.1 & 114.4 & 114.7 & 115.1 & 114.6 \\
\hline 1988 & 115.3 & 115.5 & 115.6 & 115.7 & 115.8 & 115.9 & 116.0 & 116.2 & 116.3 & 116.4 & 116.5 & 116.7 & 115.5 & 115.8 & 116.2 & 116.5 & 116.0 \\
\hline 1989 & 116.8 & 117.0 & 117.2 & 117.4 & 117.6 & 117.8 & 118.0 & 118.2 & 118.4 & 118.6 & 118.8 & 119.0 & 117.0 & 117.6 & 118.2 & 118.8 & 117.9 \\
\hline 1990 & 119.2 & 119.3 & 119.5 & 119.7 & 119.9 & 120.1 & 120.2 & 120.4 & 120.6 & 120.8 & 121.0 & 121.2 & 119.3 & 119.9 & 120.4 & 121.0 & 120.2 \\
\hline 1991 & 121.4 & 121.6 & 121.7 & 121.9 & 122.1 & 122.2 & 122.4 & 122.6 & 122.7 & 122.9 & 123.0 & 123.2 & 121.6 & 122.1 & 122.6 & 123.0 & 122.3 \\
\hline 1992 & 123.4 & 123.6 & 123.8 & 124.0 & 124.2 & 124.5 & 124.7 & 124.9 & 125.1 & 125.3 & 125.5 & 125.7 & 123.6 & 124.2 & 124.9 & 125.5 & 124.5 \\
\hline 1993 & 125.9 & 126.2 & 126.4 & 126.6 & 126.9 & 127.1 & 127.4 & 127.6 & 127.8 & 128.1 & 128.3 & 128.6 & 126.2 & 126.9 & 127.6 & 128.3 & 127.2 \\
\hline 1994 & 128.9 & 129.3 & 129.7 & 130.1 & 130.5 & 130.9 & 131.3 & 131.7 & 132.1 & 132.6 & 133.0 & 133.4 & 129.3 & 130.5 & 131.7 & 133.0 & 131.1 \\
\hline 1995 & 133.9 & 134.5 & 135.1 & 135.7 & 136.4 & 137.0 & 137.6 & 138.2 & 138.8 & 139.5 & 140.1 & 140.8 & 134.5 & 136.4 & 138.2 & 140.1 & 137.3 \\
\hline 1996 & 141.4 & 142.1 & 142.8 & 143.4 & 144.1 & 144.8 & 145.5 & 146.1 & 146.8 & 147.4 & 148.1 & 148.8 & 142.1 & 144.1 & 146.1 & 148.1 & 145.1 \\
\hline 1997 & 149.4 & 150.1 & 150.7 & 151.3 & 152.0 & 152.6 & 153.2 & 153.8 & 154.4 & 155.0 & 155.7 & 156.3 & 150.1 & 152.0 & 153.8 & 155.7 & 152.9 \\
\hline 1998 & 157.0 & 157.6 & 158.3 & 158.9 & 159.6 & 160.3 & 160.9 & 161.5 & 162.2 & 162.8 & 163.5 & & 157.6 & 159.6 & 161.5 & & $\ldots$ \\
\hline & & & & & & & & Utilizat & In (leve & percen & & & & & & & \\
\hline 1987 & 79.1 & 80.0 & 80.2 & 80.5 & 80.7 & 81.4 & 81.8 & 81.8 & 81.6 & 82.6 & 82.8 & 83.2 & 79.8 & 80.8 & 81.7 & 82.9 & 81.3 \\
\hline 1988 & 83.2 & 83.4 & 83.3 & 83.7 & 83.7 & 83.6 & 84.1 & 84.5 & 84.1 & 84.2 & 84.8 & 85.1 & 83.3 & 83.7 & 84.2 & 84.7 & 84.0 \\
\hline 1989 & 85.4 & 84.6 & 85.3 & 85.3 & 84.7 & 84.4 & 83.4 & 83.6 & 83.3 & 82.8 & 83.0 & 83.2 & 85.1 & 84.8 & 83.4 & 83.0 & 84.1 \\
\hline 1990 & 82.7 & 83.0 & 83.3 & 82.7 & 82.9 & 82.7 & 82.6 & 82.6 & 82.6 & 82.0 & 80.8 & 80.2 & 83.0 & 82.8 & 82.6 & 81.0 & 82.3 \\
\hline 1991 & 79.6 & 78.9 & 78.1 & 78.2 & 78.7 & 79.6 & 79.5 & 79.5 & 80.2 & 80.0 & 79.8 & 79.2 & 78.9 & 78.8 & 79.7 & 79.6 & 79.3 \\
\hline 1992 & 79.2 & 79.5 & 79.9 & 80.3 & 80.4 & 80.1 & 80.6 & 80.2 & 80.4 & 80.8 & 81.0 & 81.0 & 79.5 & 80.3 & 80.4 & 80.9 & 80.3 \\
\hline 1993 & 81.2 & 81.4 & 81.4 & 81.5 & 81.0 & 81.0 & 81.0 & 80.6 & 81.3 & 81.4 & 81.7 & 82.2 & 81.3 & 81.2 & 81.0 & 81.8 & 81.3 \\
\hline 1994 & 82.1 & 82.3 & 82.6 & 82.7 & 83.1 & 83.2 & 83.2 & 83.4 & 83.3 & 83.5 & 83.9 & 84.6 & 82.4 & 83.0 & 83.3 & 84.0 & 83.2 \\
\hline 1995 & 84.7 & 84.3 & 84.1 & 83.5 & 83.4 & 83.4 & 82.7 & 83.3 & 83.1 & 82.8 & 82.6 & 82.3 & 84.3 & 83.5 & 83.1 & 82.6 & 83.4 \\
\hline 1996 & 81.7 & 82.4 & 81.8 & 82.4 & 82.7 & 82.9 & 82.7 & 82.8 & 82.5 & 82.2 & 82.3 & 82.2 & 82.0 & 82.7 & 82.7 & 82.2 & 82.4 \\
\hline 1997 & 82.3 & 82.6 & 82.5 & 82.7 & 82.6 & 82.6 & 82.9 & 83.1 & 83.2 & 83.4 & 83.4 & 83.4 & 82.5 & 82.6 & 83.1 & 83.4 & 82.9 \\
\hline 1998 & 83.0 & 82.6 & 82.6 & 82.6 & 82.6 & 81.5 & 81.1 & 82.0 & 81.3 & 81.2 & 80.6 & - & 82.7 & 82.3 & 81.5 & . & $\ldots$ \\
\hline
\end{tabular}

Note. Monthly percentage change figures show change from the previous month; quarterly figures show the change from the previous quarter at a compound annual rate of growth. Production and capacity indexes are expressed as percentages of output in 1992.

In this and subsequent tables, data for September 1998 onward are subject to revision in future monthly G.17 statistical releases.

1. Annual averages of industrial production are calculated from indexes that are not seasonally adjusted. 
A.2. Revised data for industrial production, capacity, and utilization for manufacturing industries, 1987-98 Seasonally adjusted data except as noted

\begin{tabular}{|c|c|c|c|c|c|c|c|c|c|c|c|c|c|c|c|c|c|}
\hline \multirow{2}{*}{ Year } & \multirow{2}{*}{ Jan. } & \multirow{2}{*}{ Feb. } & \multirow{2}{*}{ Mar. } & \multirow{2}{*}{ Apr. } & \multirow{2}{*}{ May } & \multirow{2}{*}{ June } & \multirow{2}{*}{ July } & \multirow{2}{*}{ Aug. } & \multirow{2}{*}{ Sept. } & \multirow{2}{*}{ Oct. } & \multirow{2}{*}{ Nov. } & \multirow{2}{*}{ Dec. } & & $\mathrm{Qu}$ & rter & & nnual \\
\hline & & & & & & & & & & & & & 1 & 2 & 3 & 4 & avg. ${ }^{1}$ \\
\hline & & & & & & & Industr & 1 produ & tion (pe & centage & hange) & & & & & & \\
\hline 1987 & -.8 & 1.6 & .2 & .5 & .3 & 1.0 & .7 & -.2 & .1 & 1.3 & .5 & .6 & 5.0 & 7.0 & 5.5 & 7.6 & 5.3 \\
\hline 1988 & -.2 & .4 & -.1 & 1.0 & -.1 & .0 & .7 & .3 & .2 & .2 & .9 & .6 & 2.3 & 4.1 & 3.7 & 5.2 & 4.7 \\
\hline 1989 & .9 & -1.2 & .8 & .1 & -.7 & .0 & -1.1 & .3 & -.3 & -.6 & .4 & .1 & 4.3 & -.7 & -4.5 & -1.4 & 1.9 \\
\hline 1990 & -.2 & .9 & .3 & -.8 & .4 & -.1 & .0 & .3 & -.1 & -.6 & -1.3 & -.6 & 2.9 & -.1 & .8 & -6.3 & -.5 \\
\hline 1991 & -.9 & -.7 & -1.1 & .3 & .7 & 1.4 & .2 & .2 & 1.1 & -.1 & -.2 & -.5 & -9.7 & 1.2 & 7.8 & 1.7 & -2.4 \\
\hline 1992 & .3 & .7 & .8 & .6 & .4 & .0 & .7 & -.2 & .3 & .5 & .6 & -.1 & 2.7 & 6.8 & 3.4 & 4.0 & 4.0 \\
\hline 1993 & 9 & .2 & .2 & 6 & -.4 & .0 & .2 & -.5 & 1.2 & .4 & .5 & .9 & 4.9 & 2.1 & .5 & 6.9 & 3.7 \\
\hline 1994 & .1 & .6 & .9 & .7 & .8 & .2 & .5 & .6 & .3 & .8 & .9 & 1.1 & 6.3 & 8.8 & 5.8 & 9.2 & 6.0 \\
\hline 1995 & 6 & -.2 & .2 & -.1 & .1 & .5 & -.5 & .9 & .7 & .1 & .1 & .1 & 6.7 & 1.1 & 2.9 & 3.8 & 5.4 \\
\hline 1996 & -.3 & 1.3 & -.3 & 1.4 & 1.0 & .8 & .5 & .5 & .2 & .0 & .7 & .4 & 2.1 & 10.6 & 7.0 & 3.9 & 4.7 \\
\hline 1997 & .5 & .9 & .5 & .6 & .3 & .7 & .7 & .8 & .4 & 6 & .8 & .3 & 7.2 & 6.6 & 7.7 & 7.5 & 6.8 \\
\hline 1998 & .1 & -.1 & .3 & .6 & .3 & -1.2 & -.1 & 1.6 & -.4 & .6 & .0 & . & 2.4 & 2.5 & .4 & $\ldots$ & $\ldots$ \\
\hline & & & & & & & & dustrial & product & on (inde & & & & & & & \\
\hline 1987 & 89.6 & 91.0 & 91.2 & 91.6 & 91.9 & 92.8 & 93.4 & 93.3 & 93.4 & 94.6 & 95.1 & 95.6 & 90.6 & 92.1 & 93.4 & 95.1 & 92.8 \\
\hline 1988 & 95.4 & 95.8 & 95.7 & 96.7 & 96.6 & 96.6 & 97.3 & 97.5 & 97.7 & 97.9 & 98.9 & 99.4 & 95.6 & 96.6 & 97.5 & 98.7 & 97.1 \\
\hline 1989 & 100.3 & 99.1 & 99.9 & 100.0 & 99.4 & 99.4 & 98.3 & 98.7 & 98.4 & 97.8 & 98.2 & 98.3 & 99.8 & 99.6 & 98.5 & 98.1 & 99.0 \\
\hline 1990 & 98.1 & 99.0 & 99.3 & 98.6 & 99.0 & 98.9 & 98.8 & 99.1 & 99.0 & 98.4 & 97.2 & 96.6 & 98.8 & 98.8 & 99.0 & 97.4 & 98.5 \\
\hline 1991 & 95.8 & 95.1 & 94.1 & 94.4 & 95.0 & 96.3 & 96.6 & 96.8 & 97.8 & 97.8 & 97.6 & 97.1 & 95.0 & 95.2 & 97.0 & 97.5 & 96.2 \\
\hline 1992 & 97.4 & 98.1 & 98.9 & 99.5 & 99.9 & 99.9 & 100.6 & 100.4 & 100.7 & 101.2 & 101.8 & 101.7 & 98.1 & 99.7 & 100.6 & 101.6 & 100.0 \\
\hline 1993 & 102.6 & 102.8 & 103.0 & 103.6 & 103.2 & 103.2 & 103.4 & 102.9 & 104.1 & 104.5 & 105.1 & 106.0 & 102.8 & 103.3 & 103.5 & 105.2 & 103.7 \\
\hline 1994 & 106.1 & 106.7 & 107.6 & 108.4 & 109.3 & 109.5 & 110.1 & 110.7 & 111.1 & 112.0 & 113.0 & 114.3 & 106.8 & 109.1 & 110.7 & 113.1 & 109.9 \\
\hline 1995 & 115.0 & 114.8 & 115.1 & 115.0 & 115.1 & 115.7 & 115.1 & 116.2 & 117.0 & 117.1 & 117.2 & 117.3 & 115.0 & 115.3 & 116.1 & 117.2 & 115.9 \\
\hline 1996 & 116.9 & 118.4 & 118.1 & 119.7 & 120.9 & 121.8 & 122.4 & 123.0 & 123.3 & 123.3 & 124.2 & 124.7 & 117.8 & 120.8 & 122.9 & 124.1 & 121.4 \\
\hline 1997 & 125.3 & 126.4 & 127.0 & 127.7 & 128.1 & 129.0 & 129.8 & 130.8 & 131.4 & 132.2 & 133.3 & 133.7 & 126.2 & 128.3 & 130.7 & 133.1 & 129.7 \\
\hline 1998 & 133.8 & 133.7 & 134.1 & 134.9 & 135.4 & 133.7 & 133.6 & 135.7 & 135.2 & 136.0 & 135.9 & $\ldots$ & 133.8 & 134.7 & 134.8 & $\ldots$ & $\ldots$ \\
\hline & & & & & & & & $\mathrm{Ca}$ & acity (in & lex) & & & & & & & \\
\hline 1987 & 113.2 & 113.4 & 113.6 & 113.8 & 113.9 & 114.1 & 114.2 & 114.4 & 114.6 & 114.7 & 114.9 & 115.0 & 113.4 & 113.9 & 114.4 & 114.9 & 114.1 \\
\hline 1988 & 115.2 & 115.3 & 115.4 & 115.6 & 115.7 & 115.8 & 116.0 & 116.1 & 116.3 & 116.5 & 116.6 & 116.8 & 115.3 & 115.7 & 116.1 & 116.6 & 115.9 \\
\hline 1989 & 117.0 & 117.3 & 117.5 & 117.8 & 118.0 & 118.3 & 118.5 & 118.7 & 119.0 & 119.2 & 119.5 & 119.7 & 117.3 & 118.0 & 118.7 & 119.5 & 118.4 \\
\hline 1990 & 119.9 & 120.1 & 120.3 & 120.5 & 120.7 & 120.9 & 121.1 & 121.3 & 121.5 & 121.7 & 122.0 & 122.2 & 120.1 & 120.7 & 121.3 & 122.0 & 121.0 \\
\hline 1991 & 122.4 & 122.6 & 122.8 & 123.0 & 123.1 & 123.3 & 123.5 & 123.7 & 123.8 & 124.0 & 124.2 & 124.3 & 122.6 & 123.1 & 123.7 & 124.2 & 123.4 \\
\hline 1992 & 124.5 & 124.8 & 125.0 & 125.2 & 125.5 & 125.7 & 125.9 & 126.2 & 126.4 & 126.6 & 126.9 & 127.1 & 124.8 & 125.5 & 126.2 & 126.9 & 125.8 \\
\hline 1993 & 127.4 & 127.6 & 127.9 & 128.2 & 128.4 & 128.7 & 129.0 & 129.3 & 129.5 & 129.8 & 130.1 & 130.3 & 127.6 & 128.4 & 129.3 & 130.1 & 128.8 \\
\hline 1994 & 130.7 & 131.1 & 131.6 & 132.0 & 132.5 & 132.9 & 133.4 & 133.8 & 134.3 & 134.8 & 135.2 & 135.7 & 131.1 & 132.5 & 133.8 & 135.2 & 133.2 \\
\hline 1995 & 136.3 & 137.0 & 137.7 & 138.4 & 139.1 & 139.8 & 140.5 & 141.2 & 141.9 & 142.6 & 143.4 & 144.2 & 137.0 & 139.1 & 141.2 & 143.4 & 140.2 \\
\hline 1996 & 144.9 & 145.7 & 146.4 & 147.2 & 148.0 & 148.8 & 149.5 & 150.3 & 151.0 & 151.8 & 152.5 & 153.3 & 145.7 & 148.0 & 150.3 & 152.5 & 149.1 \\
\hline 1997 & 154.1 & 154.8 & 155.5 & 156.2 & 157.0 & 157.8 & 158.4 & 159.1 & 159.9 & 160.6 & 161.3 & 162.1 & 154.8 & 157.0 & 159.1 & 161.3 & 158.1 \\
\hline 1998 & 162.8 & 163.5 & 164.3 & 165.1 & 165.8 & 166.6 & 167.3 & 168.1 & 168.8 & 169.5 & 170.3 & $\ldots$ & 163.5 & 165.8 & 168.1 & $\ldots$ & $\ldots$ \\
\hline & & & & & & & & Jtiliza & n (level & percent & & & & & & & \\
\hline 1987 & 79.1 & 80.2 & 80.3 & 80.6 & 80.7 & 81.4 & 81.8 & 81.5 & 81.5 & 82.5 & 82.8 & 83.1 & 79.9 & 80.9 & 81.6 & 82.8 & 81.3 \\
\hline 1988 & 82.9 & 83.1 & 82.9 & 83.7 & 83.5 & 83.4 & 83.8 & 84.0 & 84.0 & 84.1 & 84.8 & 85.1 & 83.0 & 83.5 & 83.9 & 84.7 & 83.8 \\
\hline 1989 & 85.7 & 84.5 & 85.0 & 85.0 & 84.2 & 84.1 & 83.0 & 83.1 & 82.7 & 82.1 & 82.2 & 82.1 & 85.1 & 84.4 & 82.9 & 82.1 & 83.6 \\
\hline 1990 & 81.8 & 82.5 & 82.6 & 81.8 & 82.0 & 81.8 & 81.6 & 81.7 & 81.5 & 80.9 & 79.7 & 79.0 & 82.3 & 81.9 & 81.6 & 79.9 & 81.4 \\
\hline 1991 & 78.2 & 77.5 & 76.6 & 76.8 & 77.1 & 78.1 & 78.2 & 78.2 & 79.0 & 78.9 & 78.6 & 78.1 & 77.5 & 77.3 & 78.5 & 78.5 & 77.9 \\
\hline 1992 & 78.2 & 78.6 & 79.1 & 79.4 & 79.6 & 79.5 & 79.9 & 79.6 & 79.7 & 79.9 & 80.2 & 80.0 & 78.6 & 79.5 & 79.7 & 80.1 & 79.5 \\
\hline 1993 & 80.5 & 80.6 & 80.5 & 80.8 & 80.4 & 80.1 & 80.1 & 79.6 & 80.4 & 80.5 & 80.8 & 81.4 & 80.5 & 80.4 & 80.0 & 80.9 & 80.5 \\
\hline 1994 & 81.2 & 81.4 & 81.8 & 82.2 & 82.5 & 82.4 & 82.6 & 82.8 & 82.7 & 83.1 & 83.6 & 84.2 & 81.5 & 82.4 & 82.7 & 83.6 & 82.5 \\
\hline 1995 & 84.4 & 83.8 & 83.6 & 83.1 & 82.8 & 82.7 & 81.9 & 82.3 & 82.4 & 82.1 & 81.7 & 81.3 & 83.9 & 82.9 & 82.2 & 81.7 & 82.7 \\
\hline 1996 & 80.7 & 81.3 & 80.6 & 81.3 & 81.7 & 81.9 & 81.9 & 81.8 & 81.6 & 81.2 & 81.4 & 81.3 & 80.9 & 81.6 & 81.8 & 81.3 & 81.4 \\
\hline 1997 & 81.3 & 81.7 & 81.7 & 81.7 & 81.6 & 81.7 & 81.9 & 82.2 & 82.2 & 82.3 & 82.6 & 82.5 & 81.6 & 81.7 & 82.1 & 82.5 & 82.0 \\
\hline 1998 & 82.2 & 81.8 & 81.6 & 81.7 & 81.6 & 80.2 & 79.8 & 80.7 & 80.1 & 80.2 & 79.8 & $\ldots$ & 81.8 & 81.2 & 80.2 & $\ldots$ & $\ldots$ \\
\hline
\end{tabular}


A.3. Rates of growth in industrial production, by major market group, 1994-98

\begin{tabular}{|c|c|c|c|c|c|c|c|c|c|c|}
\hline \multirow[t]{2}{*}{ Market group } & \multicolumn{5}{|c|}{$\begin{array}{l}\text { Revised growth rate } \\
\text { (percent) }\end{array}$} & \multicolumn{5}{|c|}{$\begin{array}{l}\text { Difference between growth rates: } \\
\text { revised less earlier } \\
\text { (percentage points) }\end{array}$} \\
\hline & 1994 & 1995 & 1996 & 1997 & 1998 & 1994 & 1995 & 1996 & 1997 & 1998 \\
\hline Total index & 6.5 & 3.5 & 5.3 & 6.6 & 1.8 & .0 & .3 & 1.1 & .9 & .8 \\
\hline Products, total & 4.7 & 2.1 & 4.2 & 5.0 & 2.4 & .1 & .3 & .3 & .3 & 1.3 \\
\hline Final products & 4.8 & 2.6 & 4.4 & 5.6 & 2.3 & .2 & .3 & .4 & .5 & 1.6 \\
\hline Consumer goods & 4.3 & 1.3 & 2.2 & 2.7 & -.5 & -.1 & -.4 & $\begin{array}{r}.4 \\
-.2\end{array}$ & -.1 & .4 \\
\hline Durable ....... & 6.5 & .3 & 2.3 & 6.5 & 9 & -.3 & -.3 & -1.1 & .5 & 1.5 \\
\hline Automotive products & 5.4 & -2.4 & 2.0 & 9.3 & -6.5 & -.6 & -.4 & .4 & .6 & -.8 \\
\hline Autos and trucks . & 5.2 & -4.7 & 2.5 & 12.3 & -14.0 & -1.0 & -.5 & 9 & 1.2 & -1.0 \\
\hline Autos ......... & 5.8 & -7.3 & -3.8 & 3.4 & -7.0 & -.8 & -.4 & .0 & -.3 & -.3 \\
\hline Trucks & 3.0 & 1.3 & 8.1 & 15.7 & -17.0 & -1.4 & -.3 & .2 & -.2 & -.2 \\
\hline Auto parts and allied goods & 5.6 & 1.8 & $\begin{array}{l}0.1 \\
1.0\end{array}$ & 4.7 & 6.9 & .0 & -.1 & -.3 & -.3 & -.3 \\
\hline Other durable goods .......... & 7.4 & 2.5 & 2.6 & 4.3 & 7.0 & -.1 & -.3 & -2.2 & .4 & 3.6 \\
\hline Appliances and electronics & 14.4 & 9.0 & 8.9 & 11.8 & 17.5 & .9 & .1 & 1.0 & 4.1 & .4 \\
\hline Appliances and air conditioning & 2.7 & -2.0 & -.2 & -.5 & 9.5 & -.6 & -4.1 & -2.1 & .4 & -1.4 \\
\hline Home electronics ............. & 28.1 & 20.1 & 18.3 & 24.2 & 25.3 & 2.9 & 4.7 & 3.0 & 5.2 & 1.0 \\
\hline Carpeting and furniture & 5.8 & -3.0 & 3.0 & 2.4 & 3.1 & .3 & -1.6 & -2.4 & -.1 & 2.3 \\
\hline Miscellaneous ......... & 3.5 & 1.1 & -1.7 & .9 & 3.0 & -.8 & .0 & -4.2 & -1.9 & 5.2 \\
\hline Nondurable ........ & 3.7 & 1.6 & $\begin{array}{r}-1.1 \\
2.2\end{array}$ & 1.7 & $\begin{array}{l}5.0 \\
-.9\end{array}$ & $\begin{array}{l}-.0 \\
-.1\end{array}$ & -.4 & $\begin{array}{r}-4.2 \\
.1\end{array}$ & $\begin{array}{r}-1.9 \\
-.3\end{array}$ & .1 \\
\hline Nonenergy & 4.9 & .9 & 2.1 & 1.7 & -1.9 & -.1 & -.4 & .2 & -.3 & -.1 \\
\hline Foods and tobacco & 6.6 & -.3 & 1.4 & 1.3 & -1.0 & -.2 & -.7 & -.4 & -.3 & -.4 \\
\hline Clothing ........... & 4.1 & -3.5 & -.2 & -2.0 & -3.7 & -.2 & 1.9 & 3.9 & -.6 & .9 \\
\hline Chemical products & 5.3 & 5.1 & 4.9 & 2.9 & -1.9 & .1 & -.2 & .2 & -1.2 & -.5 \\
\hline Paper products .... & -.5 & 2.1 & 1.9 & 3.8 & -3.9 & -.1 & -1.6 & -.5 & 1.0 & 1.2 \\
\hline Energy products .. & -4.2 & 6.3 & 2.3 & 1.6 & 6.5 & -.1 & .0 & -.4 & -.4 & 2.2 \\
\hline Fuels ......... & -2.2 & 1.4 & 3.5 & 1.8 & 1.7 & .1 & .1 & .2 & .0 & -1.5 \\
\hline Utilities ........ & -5.1 & $\begin{array}{l}1.4 \\
8.6\end{array}$ & 1.8 & $\begin{array}{l}1.0 \\
1.5\end{array}$ & 8.9 & $\begin{array}{r}.1 \\
-.1\end{array}$ & $\begin{array}{l}.1 \\
-.2\end{array}$ & -.8 & -.4 & $\begin{array}{r}-1.5 \\
4.1\end{array}$ \\
\hline Equipment, total & 5.8 & 4.6 & 8.0 & 10.4 & 6.5 & .7 & 1.5 & 1.2 & 1.6 & 3.4 \\
\hline Business equipment & 9.4 & 7.0 & 9.8 & 13.1 & 9.0 & .8 & 1.6 & 1.5 & 2.3 & 4.3 \\
\hline Information processing and related & 13.4 & 14.9 & 16.5 & 16.2 & 15.4 & $\begin{array}{r}.0 \\
-.1\end{array}$ & 1.9 & 4.7 & 4.0 & 6.2 \\
\hline Computer and office ............... & 29.5 & 44.7 & 41.9 & 43.7 & 58.1 & -.3 & 1.7 & 4.5 & 9.2 & 10.4 \\
\hline Industrial ............. & 10.0 & 8.5 & 1.2 & 5.2 & 3.0 & .1 & .8 & 1.2 & -.5 & .1 \\
\hline Transit ............. & 1.5 & -9.4 & 14.3 & 22.8 & 9.7 & 4.1 & 3.3 & -4.9 & 5.2 & 7.3 \\
\hline Autos and trucks & 8.4 & -6.0 & -3.0 & 12.3 & -8.3 & 5.7 & 1.6 & -2.9 & 3.8 & .1 \\
\hline Other & 5.9 & 1.9 & 5.5 & 10.4 & 9 & -.2 & .1 & .7 & .9 & 3.3 \\
\hline Defense and space equipment & -6.7 & -7.2 & -1.0 & $\begin{array}{l}10.4 \\
-3.9\end{array}$ & .5 & .9 & 1.5 & .5 & -1.3 & -.2 \\
\hline Oil and gas well drilling..... & $\begin{array}{l}-0.1 \\
-6.7\end{array}$ & $\begin{array}{r}-1.2 \\
2.4\end{array}$ & $\begin{array}{r}-1.0 \\
7.6\end{array}$ & $\begin{array}{r}-3.9 \\
9.4\end{array}$ & -19.8 & 3 & .4 & .6 & $\begin{array}{r}-1.3 \\
.2\end{array}$ & -2.0 \\
\hline Manufactured homes .... & $\begin{array}{r}-0.1 \\
8.6\end{array}$ & 8.7 & $\begin{array}{l}1.0 \\
-.7\end{array}$ & $\begin{array}{l}9.4 \\
-.7\end{array}$ & $\begin{array}{r}-19.0 \\
6.7\end{array}$ & 1.0 & 2.0 & .2 & .5 & -5.0 \\
\hline Intermediate products .. & 4.3 & .5 & 3.8 & 3.2 & 2.6 & -.1 & .0 & .0 & -.4 & .4 \\
\hline Construction supplies & 7.2 & -.3 & 5.9 & 2.4 & 4.8 & .0 & .2 & .1 & .2 & -1.3 \\
\hline Business supplies . & 2.5 & 1.1 & 2.4 & 3.8 & 1.3 & -.2 & -.2 & .0 & -.8 & 1.3 \\
\hline Materials . & 9.3 & 5.7 & 6.9 & 9.0 & .9 & -.3 & .3 & 2.2 & 1.7 & .1 \\
\hline Durable ............. & 13.5 & 11.0 & 10.2 & 13.3 & 2.0 & -.4 & .6 & 3.5 & 2.1 & .7 \\
\hline Consumer parts & 10.3 & 3.6 & 1.2 & 7.3 & -4.8 & .2 & 1.3 & 1.1 & .4 & 0 \\
\hline Equipment parts & 21.4 & 26.3 & 22.7 & 26.4 & 10.0 & -1.3 & .5 & 7.8 & 4.8 & 1.7 \\
\hline Semiconductors, printed circuit boards, & & & & & & & & & & \\
\hline and other electrical components . & 53.2 & 65.4 & 49.4 & 53.3 & 20.7 & n.a. & n.a. & n.a. & n.a. & n.a. \\
\hline Other .......... & 8.9 & 2.3 & 3.9 & 5.0 & $\begin{array}{l}-2.1 \\
-47\end{array}$ & $\begin{array}{l}-.1 \\
-2\end{array}$ & .2 & .8 & .4 & .0 \\
\hline Basic metals & 6.9 & $\begin{array}{r}1.6 \\
-25\end{array}$ & $\begin{array}{l}3.9 \\
3.6\end{array}$ & $\begin{array}{l}4.3 \\
4.5\end{array}$ & $\begin{array}{l}-4.7 \\
-2.6\end{array}$ & $\begin{array}{l}-.2 \\
-2\end{array}$ & $\begin{array}{r}.2 \\
-1\end{array}$ & $\begin{array}{r}1.3 \\
-1\end{array}$ & -.4 & -.7 \\
\hline Nondurable & 5.9 & -2.5 & 3.6 & 4.5 & -2.6 & -.2 & -.1 & -.1 & 1.0 & -.5 \\
\hline Textile & 8.9 & $\begin{array}{l}-7.2 \\
-2.8\end{array}$ & $\begin{array}{l}2.7 \\
4.3\end{array}$ & $\begin{array}{l}3.2 \\
4.7\end{array}$ & $\begin{array}{l}-5.2 \\
-1.4\end{array}$ & $\begin{array}{l}-.2 \\
-.1\end{array}$ & .11 & $\begin{array}{l}1.8 \\
1.4\end{array}$ & -.7 & $\begin{array}{r}.5 \\
-3 \\
\end{array}$ \\
\hline $\begin{array}{l}\text { Paper .... } \\
\text { Chemical }\end{array}$ & $\begin{array}{l}5.1 \\
5.7\end{array}$ & $\begin{array}{r}-2.8 \\
-.8\end{array}$ & 5.1 & 5.0 & $\begin{array}{l}-1.4 \\
-4.0\end{array}$ & $\begin{array}{l}-.1 \\
-.4\end{array}$ & $\begin{array}{l}1.1 \\
-.6\end{array}$ & $\begin{array}{l}1.4 \\
-1.0\end{array}$ & 1.7 & -1.5 \\
\hline Other ... & 5.6 & -3.0 & .5 & 3.8 & .4 & -.2 & -.2 & -.1 & .0 & 1.1 \\
\hline Energy & 2.0 & .6 & .8 & .3 & 1.9 & -.1 & -.2 & .3 & -.8 & $\begin{array}{l}1.1 \\
-.9\end{array}$ \\
\hline Primary ....... & 3.3 & .3 & -.7 & .2 & 1.9 & .0 & -.2 & .3 & -.2 & -1.4 \\
\hline Converted fuel & -.3 & 1.1 & 3.6 & .5 & 1.9 & -.1 & -.1 & .6 & -1.8 & .0 \\
\hline Special aggregates & & & & & & & & & & \\
\hline otal excluding: & 61 & 20 & 46 & 50 & 7 & 0 & 2 & 0 & 6 & 5 \\
\hline Is and once equipinent. & & & & & & & & & & \\
\hline Business equipment excluding: & 77 & 38 & 68 & 105 & 46 & 8 & 15 & 11 & 15 & 30 \\
\hline
\end{tabular}

NoTE. Growth rates are calculated as the percentage change in the seasonally of the year specified. For 1998, the growth rates are calculated from the fourth adjusted index from the fourth quarter of the previous year to the fourth quarter quarter of 1997 to the third quarter of 1998 and annualized. 
A.4. Rates of growth in industrial production, by industry group, 1994-98

\begin{tabular}{|c|c|c|c|c|c|c|c|c|c|c|c|}
\hline \multirow[t]{2}{*}{ Series } & \multirow{2}{*}{$\begin{array}{l}\text { SIC } \\
\text { code }^{1}\end{array}$} & \multicolumn{5}{|c|}{$\begin{array}{l}\text { Revised growth rate } \\
\text { (percent) }\end{array}$} & \multicolumn{5}{|c|}{$\begin{array}{l}\text { Difference between growth rates: } \\
\text { revised less earlier } \\
\text { (percentage points) }\end{array}$} \\
\hline & & 1994 & 1995 & 1996 & 1997 & 1998 & 1994 & 1995 & 1996 & 1997 & 1998 \\
\hline Total index & $\ldots$ & 6.5 & 3.5 & 5.3 & 6.6 & 1.8 & .0 & .3 & 1.1 & .9 & .8 \\
\hline Manufacturing .... & . & 7.5 & 3.6 & 5.9 & 7.3 & 1.8 & .0 & .3 & 1.2 & .9 & 1.0 \\
\hline $\begin{array}{l}\text { Primary processing ... } \\
\text { Advanced processing }\end{array}$ & & $\begin{array}{l}6.5 \\
8.0\end{array}$ & $\begin{array}{l}-.3 \\
5.5\end{array}$ & $\begin{array}{l}4.1 \\
6.7\end{array}$ & $\begin{array}{l}3.9 \\
8.8\end{array}$ & $\begin{array}{l}-.9 \\
3.0\end{array}$ & $\begin{array}{r}-.1 \\
.0\end{array}$ & $\begin{array}{l}.1 \\
.4\end{array}$ & .66 & $\begin{array}{r}.4 \\
1.2\end{array}$ & $\begin{array}{l}-.3 \\
1.7\end{array}$ \\
\hline $\begin{array}{c}\text { Durable manufacturing } \ldots \ldots \ldots \ldots \\
\text { Lumber and products } \ldots \ldots \ldots \ldots \\
\text { Furniture and fixtures } \ldots \ldots \ldots \ldots \\
\text { Stone, clay, and glass products }\end{array}$ & $\begin{array}{l}24 \\
25 \\
32\end{array}$ & $\begin{array}{l}9.9 \\
5.3 \\
5.6 \\
5.2\end{array}$ & $\begin{array}{r}6.9 \\
.8 \\
-.8 \\
2.7\end{array}$ & $\begin{array}{l}8.6 \\
1.8 \\
4.7 \\
6.3\end{array}$ & $\begin{array}{r}11.1 \\
3.1 \\
3.3 \\
2.6\end{array}$ & $\begin{array}{l}4.2 \\
3.7 \\
1.4 \\
2.5\end{array}$ & $\begin{array}{r}.0 \\
.2 \\
.3 \\
-.3\end{array}$ & $\begin{array}{r}.8 \\
-.4 \\
-1.2 \\
1.2\end{array}$ & $\begin{array}{r}2.1 \\
-1.0 \\
-2.6 \\
2.5\end{array}$ & $\begin{array}{r}1.6 \\
1.0 \\
-.3 \\
-2.0\end{array}$ & $\begin{array}{r}1.8 \\
-1.1 \\
3.8 \\
2.5\end{array}$ \\
\hline $\begin{array}{l}\text { Primary metals } \ldots \ldots \ldots \ldots \ldots \ldots \\
\text { Iron and steel } \ldots \ldots \ldots \ldots \ldots \ldots \ldots \\
\text { Raw steel } \ldots \ldots \ldots \ldots \ldots \ldots \ldots \ldots \\
\text { Nonferrous metals } \ldots \ldots \ldots \ldots \ldots \ldots \ldots \\
\text { Fabricated metal products } \ldots \ldots \ldots \ldots \\
\text { Industrial machinery and equipment } \\
\text { Computer and office equipment } \\
\text { Electrical machinery } \ldots \ldots \ldots \ldots \ldots \ldots\end{array}$ & $\begin{array}{r}33 \\
331,2 \\
331 \mathrm{pt} \\
333-6,9 \\
34 \\
35 \\
357 \\
36\end{array}$ & $\begin{array}{r}8.7 \\
7.7 \\
6.2 \\
10.1 \\
8.9 \\
15.3 \\
30.8 \\
25.4\end{array}$ & $\begin{array}{r}-.2 \\
-.3 \\
.7 \\
-.1 \\
1.2 \\
14.1 \\
41.6 \\
25.9\end{array}$ & $\begin{array}{r}4.6 \\
3.6 \\
-1.7 \\
5.9 \\
4.1 \\
9.8 \\
42.9 \\
22.2\end{array}$ & $\begin{array}{r}4.9 \\
5.0 \\
7.3 \\
4.9 \\
4.5 \\
13.4 \\
43.6 \\
24.2\end{array}$ & $\begin{array}{r}-6.4 \\
-9.6 \\
-2.6 \\
-2.5 \\
-3 \\
14.8 \\
55.9 \\
9.2\end{array}$ & $\begin{array}{r}-.2 \\
-.1 \\
.0 \\
-.3 \\
-.1 \\
.0 \\
.4 \\
-1.8\end{array}$ & $\begin{array}{r}.2 \\
.6 \\
.0 \\
-.3 \\
.0 \\
1.6 \\
3.7 \\
.2\end{array}$ & $\begin{array}{r}1.1 \\
1.3 \\
.0 \\
.9 \\
.9 \\
2.1 \\
6.4 \\
9.6\end{array}$ & $\begin{array}{r}-.7 \\
-.7 \\
.0 \\
-.6 \\
.7 \\
.7 \\
7.2 \\
5.7\end{array}$ & $\begin{array}{r}-1.1 \\
-1.1 \\
.0 \\
-.8 \\
.8 \\
4.0 \\
5.6 \\
1.6\end{array}$ \\
\hline $\begin{array}{l}\text { Semiconductors and related } \\
\text { electronic components }\end{array}$ & $3672-9$ & 48.8 & 58.0 & 44.6 & 48.6 & 18.0 & -6.1 & -1.3 & 19.1 & 8.8 & .6 \\
\hline $\begin{array}{r}\text { Transportation equipment ...... } \\
\text { Motor vehicles and parts } \ldots . \\
\text { Autos and light trucks } \ldots .\end{array}$ & $\begin{array}{r}37 \\
371 \\
371 \mathrm{pt}\end{array}$ & $\begin{array}{l}2.1 \\
8.9 \\
4.2\end{array}$ & $\begin{array}{r}-4.2 \\
-.6 \\
-5.1\end{array}$ & $\begin{array}{r}4.9 \\
-1.4 \\
1.9\end{array}$ & $\begin{array}{l}13.1 \\
12.8 \\
10.9\end{array}$ & $\begin{array}{r}-1.3 \\
-9.2 \\
-12.9\end{array}$ & $\begin{array}{r}.8 \\
1.1 \\
-1.0\end{array}$ & $\begin{array}{l}1.0 \\
1.0 \\
-.6\end{array}$ & $\begin{array}{r}-.6 \\
.0 \\
.9\end{array}$ & $\begin{array}{r}.9 \\
.9 \\
1.3\end{array}$ & $\begin{array}{r}2.1 \\
.0 \\
-1.1\end{array}$ \\
\hline 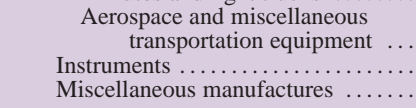 & $\begin{array}{r}372-6,9 \\
38 \\
39\end{array}$ & $\begin{array}{r}-6.7 \\
1.9 \\
3.8\end{array}$ & $\begin{array}{r}-9.7 \\
4.2 \\
2.5\end{array}$ & $\begin{array}{r}15.3 \\
3.0 \\
2.7\end{array}$ & $\begin{array}{r}13.4 \\
3.6 \\
1.4\end{array}$ & $\begin{array}{r}9.9 \\
1.3 \\
-1.6\end{array}$ & $\begin{array}{r}.4 \\
1.3 \\
-.2\end{array}$ & $\begin{array}{l}1.1 \\
2.3 \\
-.7\end{array}$ & $\begin{array}{l}-1.7 \\
-1.2 \\
-2.5\end{array}$ & $\begin{array}{r}.8 \\
.3 \\
-3.4\end{array}$ & $\begin{array}{r}5.1 \\
.7 \\
-.6\end{array}$ \\
\hline $\begin{array}{c}\text { Nondurable manufacturing } . \\
\text { Foods .................. } \\
\text { Tobacco products ....... } \\
\text { Textile mill products .... } \\
\text { Apparel products ........ } \\
\text { Paper and products ....... }\end{array}$ & $\begin{array}{l}20 \\
21 \\
22 \\
23 \\
26\end{array}$ & $\begin{array}{r}4.8 \\
2.3 \\
43.6 \\
5.9 \\
6.4 \\
4.5\end{array}$ & $\begin{array}{r}-.3 \\
.5 \\
-4.4 \\
-4.6 \\
-3.6 \\
-2.5\end{array}$ & $\begin{array}{l}2.6 \\
1.1 \\
-.1 \\
1.9 \\
-.9 \\
3.0\end{array}$ & $\begin{array}{r}2.6 \\
1.9 \\
-.8 \\
3.5 \\
-2.0 \\
4.2\end{array}$ & $\begin{array}{r}-1.3 \\
-.4 \\
-5.3 \\
-1.6 \\
-4.0 \\
-.9\end{array}$ & $\begin{array}{r}-.1 \\
-.1 \\
.0 \\
.0 \\
-.2 \\
-.2\end{array}$ & $\begin{array}{r}-.2 \\
-1.1 \\
.8 \\
.6 \\
.9 \\
.4\end{array}$ & $\begin{array}{r}.1 \\
-.6 \\
-2.4 \\
1.8 \\
2.5 \\
.7\end{array}$ & $\begin{array}{r}.0 \\
.0 \\
-2.7 \\
-.5 \\
-.1 \\
1.1\end{array}$ & $\begin{array}{r}-.1 \\
.2 \\
-3.8 \\
.8 \\
.1 \\
-.6\end{array}$ \\
\hline $\begin{array}{l}\text { Printing and publishing } . . . . \\
\text { Chemicals and products } \ldots . \\
\text { Petroleum products ...... } \\
\text { Rubber and plastic products } \\
\text { Leather and products ....... }\end{array}$ & $\begin{array}{l}27 \\
28 \\
29 \\
30 \\
31\end{array}$ & $\begin{array}{r}1.1 \\
4.6 \\
-.8 \\
9.6 \\
-8.4\end{array}$ & $\begin{array}{r}-.2 \\
1.6 \\
.7 \\
.2 \\
-5.6\end{array}$ & $\begin{array}{l}1.9 \\
4.9 \\
3.7 \\
4.0 \\
1.3\end{array}$ & $\begin{array}{r}3.6 \\
3.1 \\
2.0 \\
4.3 \\
-8.7\end{array}$ & $\begin{array}{r}-2.2 \\
-2.5 \\
3.0 \\
2.3 \\
-8.3\end{array}$ & $\begin{array}{r}-.1 \\
-.1 \\
.1 \\
.0 \\
.5\end{array}$ & $\begin{array}{r}-.2 \\
-.5 \\
.2 \\
.2 \\
5.4\end{array}$ & $\begin{array}{r}.3 \\
-.5 \\
.4 \\
.7 \\
5.3\end{array}$ & $\begin{array}{r}-.3 \\
.2 \\
-.2 \\
.4 \\
-1.5\end{array}$ & $\begin{array}{r}2.7 \\
-1.2 \\
-3.0 \\
-.1 \\
2.0\end{array}$ \\
\hline 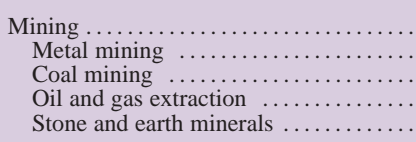 & $\begin{array}{l}10 \\
12 \\
13 \\
14\end{array}$ & $\begin{array}{r}.8 \\
-3.2 \\
8.9 \\
-1.2 \\
6.7\end{array}$ & $\begin{array}{r}-.9 \\
4.6 \\
-1.4 \\
-1.4 \\
-1.1\end{array}$ & $\begin{array}{l}2.0 \\
4.6 \\
4.3 \\
1.0 \\
4.8\end{array}$ & $\begin{array}{l}2.1 \\
4.4 \\
2.2 \\
1.8 \\
3.4\end{array}$ & $\begin{array}{r}-2.7 \\
-6.1 \\
5.9 \\
-5.1 \\
2.3\end{array}$ & $\begin{array}{r}-.1 \\
-.2 \\
-.2 \\
.1 \\
-.2\end{array}$ & $\begin{array}{r}-.1 \\
.1 \\
-1.3 \\
.1 \\
.0\end{array}$ & $\begin{array}{r}.4 \\
1.2 \\
1.8 \\
.1 \\
-.5\end{array}$ & $\begin{array}{r}.0 \\
1.7 \\
-2.5 \\
-.1 \\
2.8\end{array}$ & $\begin{array}{r}-2.5 \\
.0 \\
3.2 \\
-3.5 \\
-7.7\end{array}$ \\
\hline $\begin{array}{l}\text { Utilities } \ldots \ldots \ldots \ldots \ldots \\
\text { Electric } \ldots \ldots \ldots \ldots \ldots \\
\text { Gas } \ldots \ldots \ldots \ldots \ldots \ldots\end{array}$ & $\begin{array}{l}491,493 \mathrm{pt} \\
492,493 \mathrm{pt}\end{array}$ & $\begin{array}{r}-.4 \\
1.7 \\
-8.0\end{array}$ & $\begin{array}{r}6.3 \\
5.2 \\
10.8\end{array}$ & $\begin{array}{l}1.1 \\
1.0 \\
1.8\end{array}$ & $\begin{array}{r}1.9 \\
2.6 \\
-1.3\end{array}$ & $\begin{array}{l}6.4 \\
7.1 \\
2.9\end{array}$ & $\begin{array}{r}-.1 \\
.0 \\
-.3\end{array}$ & $\begin{array}{r}-.1 \\
-.1 \\
.0\end{array}$ & $\begin{array}{r}-.3 \\
.0 \\
-1.3\end{array}$ & $\begin{array}{r}-.5 \\
-.3 \\
-2.1\end{array}$ & $\begin{array}{l}1.9 \\
1.0 \\
4.9\end{array}$ \\
\hline $\begin{array}{l}\text { Special aggregates } \\
\text { Computers, communications equipment, } \\
\quad \text { and semiconductors }{ }^{2} \ldots \ldots \ldots \ldots \ldots . .\end{array}$ & & 36.6 & 42.0 & 36.7 & 38.5 & 25.1 & -2.6 & 1.4 & 13.8 & 7.9 & 4.8 \\
\hline $\begin{array}{l}\text { Manufacturing excluding computers, } \\
\text { communications equipment, and } \\
\text { semiconductors }{ }^{2} \ldots \ldots \ldots \ldots \ldots\end{array}$ & & 5.4 & .5 & 3.0 & 4.3 & -.5 & .1 & .3 & .0 & .1 & .5 \\
\hline $\begin{array}{l}\text { Manufacturing excluding motor vehicles } \\
\text { and parts } \ldots \ldots \ldots \ldots \ldots \ldots \ldots \ldots \ldots \ldots \ldots \ldots \ldots\end{array}$ & & 7.4 & 3.9 & 6.4 & 6.9 & 2.5 & -.1 & .3 & 1.3 & 1.0 & 1.1 \\
\hline
\end{tabular}

NotE. Growth rates are calculated as the percentage change in the seasonally adjusted index from the fourth quarter of the previous year to the fourth quarter of the year specified. For 1998, the growth rates are calculated from the fourth quarter of 1997 to the third quarter of 1998 and annualized.

Primary-processing manufacturing includes textile mill products; paper and products; industrial chemicals, synthetic materials, and fertilizers; petroleum products; rubber and plastics products; lumber and products; primary metals; fabricated metals; and stone, clay, and glass products. Advanced-processing manufacturing includes foods, tobacco products, apparel products, printing and

publishing, chemical products and other agricultural chemicals, leather and products, furniture and fixtures, industrial and commercial machinery and computer equipment, electrical machinery, transportation equipment, instruments, and miscellaneous manufactures.

1. Standard Industrial Classification; see Executive Office of the President, Office of Management and Budget, Standard Industrial Classification Manual, 1987 (U.S. Government Printing Office, 1987).

2. Semiconductors include related electronic components.

pt Part of classification. 
A.5. Rates of growth in capacity, by industry group, 1994-98

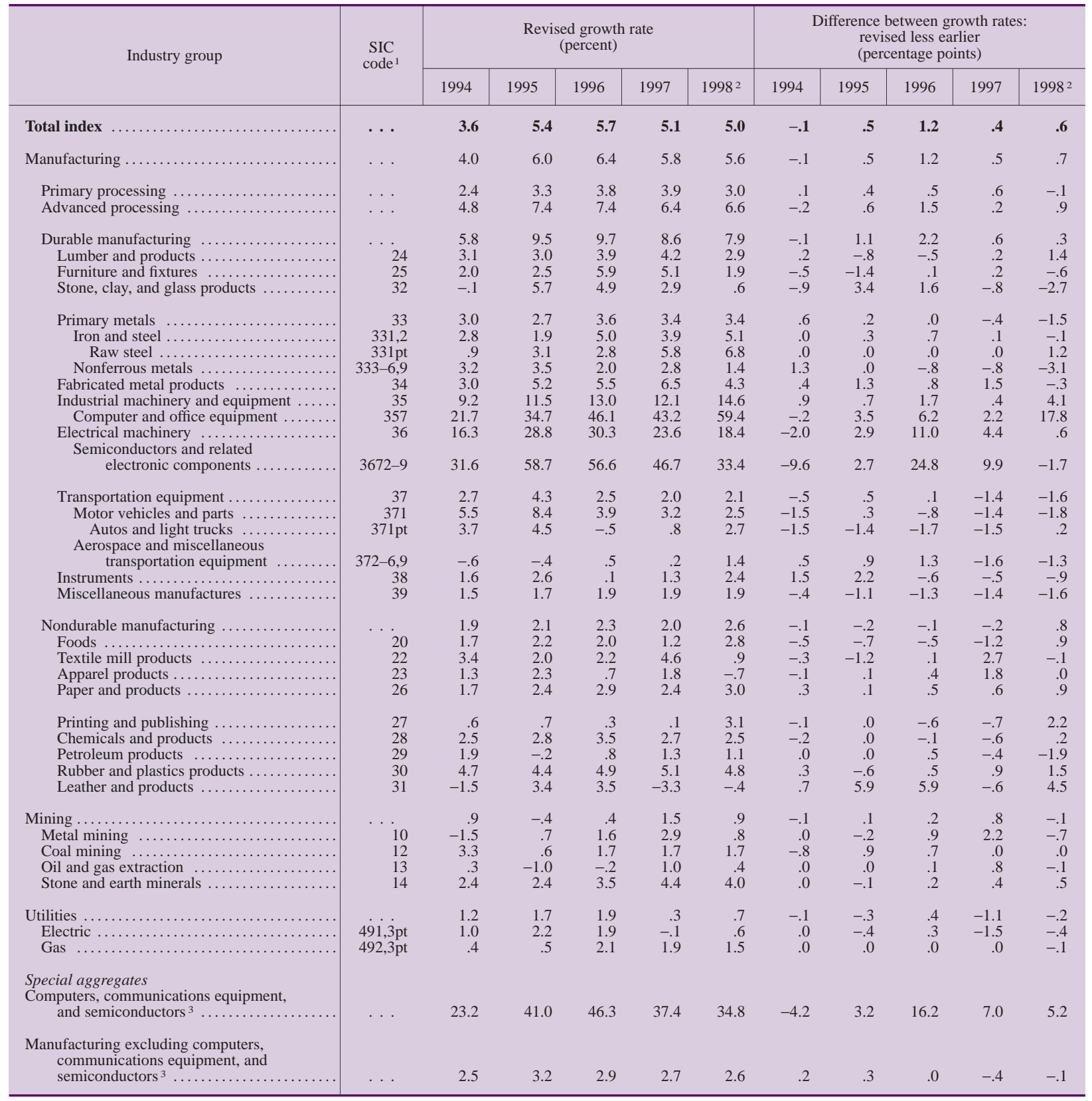

Note. See general note to table A.4.

1. Standard Industrial Classification; see table A.4, note 1 .

3. Semiconductors include related electronic components.

2. Through the fourth quarter of 1998 . 
A.6. Capacity utilization rates, by industry group, 1967-98

\begin{tabular}{|c|c|c|c|c|c|c|c|c|c|c|}
\hline \multirow{2}{*}{ Item } & \multirow{2}{*}{$\begin{array}{l}\text { SIC } \\
\text { code }^{1}\end{array}$} & \multicolumn{6}{|c|}{$\begin{array}{c}\text { Revised rate } \\
\text { (percent of capacity, seasonally adjusted) }\end{array}$} & \multicolumn{3}{|c|}{$\begin{array}{l}\text { Difference between rates: } \\
\text { revised less earlier } \\
\text { (percentage points) }\end{array}$} \\
\hline & & $\begin{array}{l}\text { 1967-97 } \\
\text { avg. }\end{array}$ & $\begin{array}{l}\text { 1988-89 } \\
\text { high }\end{array}$ & $\begin{array}{l}\text { 1990-91 } \\
\text { low }\end{array}$ & 1996:Q4 & 1997:Q4 & 1998:Q3 & 1996:Q4 & 1997:Q4 & 1998:Q3 \\
\hline Total index & $\ldots$ & 82.1 & 85.4 & 78.1 & 82.2 & 83.4 & 81.5 & -.1 & .2 & .3 \\
\hline Manufacturing & . . . & 81.1 & 85.7 & 76.6 & 81.3 & 82.5 & 80.2 & -.1 & .3 & 6 \\
\hline Primary processing . . & $\ldots$ & 82.3 & 88.9 & 77.7 & 85.4 & 85.3 & 82.8 & -.5 & -.7 & -.9 \\
\hline Advanced processing & $\ldots$ & 80.5 & 84.2 & 76.1 & 79.6 & 81.4 & 79.3 & .2 & 1.0 & 1.4 \\
\hline Durable manufacturing & & 79.4 & 84.6 & 73.1 & 80.2 & 82.1 & 79.9 & -.2 & .5 & 1.4 \\
\hline Lumber and products & 24 & 82.5 & 93.6 & 75.5 & 82.1 & 81.3 & 81.7 & -.6 & .1 & -1.4 \\
\hline Furniture and fixtures & 25 & 81.4 & 86.6 & 72.5 & 79.2 & 77.9 & 77.6 & -1.8 & -2.1 & .4 \\
\hline Stone, clay, and glass products .. & 32 & 78.2 & 83.5 & 69.7 & 80.9 & 80.7 & 81.7 & -.5 & -1.4 & 1.7 \\
\hline Primary metals & 33 & 81.1 & 92.7 & 73.7 & 90.7 & 92.0 & 85.4 & -.1 & -.3 & -.1 \\
\hline Iron and steel & 331,2 & 81.1 & 95.2 & 71.8 & 90.9 & 91.8 & 82.0 & .7 & .0 & -.7 \\
\hline Raw steel & $331 \mathrm{pt}$ & 80.9 & 92.7 & 71.5 & 88.8 & 90.0 & 84.0 & .1 & .1 & -.6 \\
\hline Nonferrous metals & $333-6,9$ & 81.3 & 89.3 & 74.2 & 90.5 & 92.3 & 89.6 & -1.0 & -.9 & .7 \\
\hline Fabricated metal products $\ldots . \ldots \ldots$ & 34 & 78.0 & 82.0 & 71.9 & 80.3 & 78.8 & 76.1 & -.3 & -.8 & -.1 \\
\hline Industrial machinery and equipment & 35 & 81.3 & 85.4 & 72.3 & 84.4 & 85.4 & 85.6 & -.4 & .9 & 1.0 \\
\hline Computer and office equipment .. & 357 & 81.2 & 86.9 & 66.9 & 83.3 & 83.5 & 82.5 & .8 & 3.7 & -1.0 \\
\hline Electrical machinery $\ldots \ldots \ldots \ldots$ & 36 & 81.1 & 84.0 & 75.0 & 81.3 & 81.7 & 76.6 & -.7 & .2 & .6 \\
\hline $\begin{array}{r}\text { Semiconductors and related } \\
\text { electronic components }\end{array}$ & $3672-9$ & 80.0 & 81.1 & 75.6 & 82.7 & 83.8 & 76.0 & -.6 & -1.3 & -.5 \\
\hline Transportation equipment & 37 & 75.9 & 85.8 & 68.5 & 72.2 & 80.0 & 78.0 & .3 & 2.0 & 4.0 \\
\hline Motor vehicles and parts & 371 & 76.8 & 89.1 & 55.9 & 74.4 & 81.3 & 74.2 & 2.3 & 4.2 & 4.7 \\
\hline Autos and light trucks ${ }^{2} \ldots$ & $371 \mathrm{pt}$ & $\ldots$ & 92.3 & 53.3 & 79.6 & 87.6 & 77.3 & 3.0 & 5.5 & 4.1 \\
\hline $\begin{array}{l}\text { Aerospace and miscellaneous } \\
\text { transportation equipment }\end{array}$ & $372-6,9$ & 75.0 & 87.3 & 792 & 693 & 784 & 833 & -22 & -7 & 30 \\
\hline Instruments $\ldots \ldots \ldots \ldots \ldots \ldots$ & $\begin{array}{r}3 / 2-0,9 \\
38\end{array}$ & $\begin{array}{l}75.0 \\
81.7\end{array}$ & $\begin{array}{l}81.3 \\
81.4\end{array}$ & 77.2 & $\begin{array}{l}69.3 \\
79.1\end{array}$ & $\begin{array}{l}18.4 \\
80.8\end{array}$ & $\begin{array}{l}83.3 \\
80.2\end{array}$ & $\begin{array}{r}-2.2 \\
-.4\end{array}$ & $\begin{array}{r}-.7 \\
.3\end{array}$ & $\begin{array}{l}3.0 \\
1.2\end{array}$ \\
\hline Miscellaneous manufactures ... & 39 & 75.6 & 79.0 & 71.7 & 80.1 & 79.7 & 77.6 & .9 & -.7 & -.1 \\
\hline Nondurable manufacturing & & 83.4 & 87.3 & 80.7 & 82.8 & 83.3 & 81.0 & .2 & .4 & -.1 \\
\hline Foods $\ldots \ldots \ldots \ldots \ldots$ & 20 & 83.0 & 85.4 & 82.7 & 81.6 & 82.1 & 80.2 & .7 & 1.6 & 1.3 \\
\hline Textile mill products & 22 & 85.7 & 90.4 & 77.7 & 85.5 & 84.7 & 83.0 & 3.0 & .4 & .9 \\
\hline Apparel products .... & 23 & 81.1 & 85.1 & 75.5 & 79.1 & 76.2 & 74.2 & 2.2 & 8 & 8 \\
\hline Paper and products . & 26 & 89.2 & 93.5 & 85.0 & 87.8 & 89.3 & 86.8 & -.7 & -.3 & -1.2 \\
\hline Printing and publishing . & 27 & 85.8 & 91.7 & 79.6 & 82.1 & 85.1 & 81.9 & .7 & 1.0 & 1.5 \\
\hline Chemicals and products & 28 & 79.5 & 86.2 & 79.3 & 79.5 & 79.8 & 76.8 & -.2 & .4 & -.4 \\
\hline Petroleum products .... & 29 & 86.6 & 88.5 & 85.1 & 94.5 & 95.2 & 96.5 & .1 & .3 & -.5 \\
\hline Rubber and plastics products & 30 & 84.5 & 89.6 & 77.4 & 86.2 & 85.5 & 84.0 & -1.7 & -2.1 & -3.0 \\
\hline Leather and products $\ldots \ldots \ldots$ & 31 & 80.8 & 83.3 & 76.1 & 70.9 & 66.9 & 63.0 & -.4 & -1.0 & -1.9 \\
\hline Mining . & & 87.5 & 88.0 & 87.0 & 88.1 & 88.6 & 86.3 & -.2 & -.9 & -2.5 \\
\hline Metal mining & 10 & 79.1 & 89.4 & 79.9 & 90.8 & 92.2 & 87.3 & .4 & -.1 & .2 \\
\hline Coal mining & 12 & 86.6 & 91.5 & 83.4 & 84.2 & 84.5 & 87.1 & -2.0 & -4.2 & -2.3 \\
\hline Oil and gas extraction & 13 & 88.6 & 88.2 & 88.7 & 88.9 & 89.6 & 86.0 & .2 & -.6 & -2.9 \\
\hline Stone and earth minerals & 14 & 84.8 & 89.0 & 79.4 & 86.3 & 85.5 & 84.5 & -.5 & 1.5 & -3.4 \\
\hline Utilities & & 87.3 & 92.6 & 83.4 & 89.4 & 90.8 & 94.6 & -6 & -.1 & 1.4 \\
\hline Electric . & $491,3 \mathrm{pt}$ & 89.2 & 95.0 & 87.1 & 90.8 & 93.2 & 97.7 & -.1 & 1.0 & 2.0 \\
\hline Gas $\ldots \ldots \ldots \ldots \ldots$ & $492,3 \mathrm{pt}$ & 82.4 & 85.0 & 67.1 & 83.7 & 81.1 & 81.9 & -1.6 & -3.3 & -.2 \\
\hline $\begin{array}{l}\text { Special aggregates } \\
\text { Computers, communications equipment, } \\
\quad \text { and semiconductors }{ }^{3} \ldots \ldots \ldots \ldots \ldots\end{array}$ & $\cdots$ & 80.3 & 81.9 & 72.4 & 81.4 & 82.0 & 77.4 & .2 & .7 & .7 \\
\hline $\begin{array}{l}\text { Manufacturing excluding computers, } \\
\text { communications equipment, and } \\
\text { semiconductors }{ }^{3} \ldots \ldots \ldots \ldots \ldots\end{array}$ & . & 81.2 & 86.1 & 76.8 & 81.3 & 82.6 & 80.7 & -.1 & .3 & 6 \\
\hline
\end{tabular}

NoTE. The "high" column refers to periods in which utilization generally peaked; the "low" column refers to recession years in which utilization gener-

1. Standard Industrial Classification; see table A.4, note 1 . ally bottomed out. The monthly highs and lows are specific to each series, and

2. Series begins in 1977 .

all did not occur in the same month.

3. Semiconductors include related electronic components.

pt Part of classification. 
A.7. Annual proportions in industrial production, by industry group, 1990-97

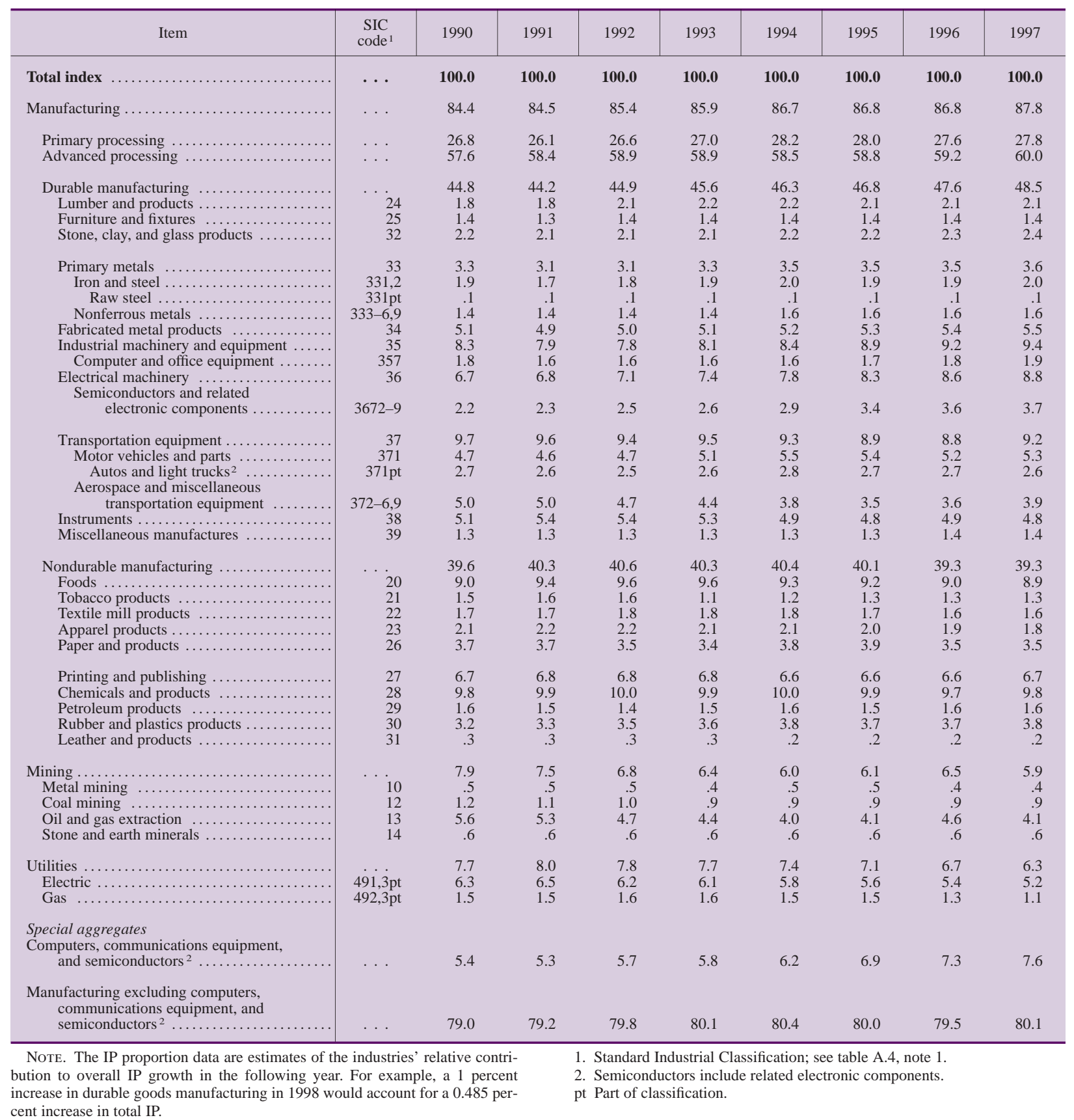


A.8. Rates of growth in electric power use, 1994-98

\begin{tabular}{|c|c|c|c|c|c|c|c|c|c|c|c|}
\hline \multirow[t]{2}{*}{ Item } & \multirow{2}{*}{$\begin{array}{l}\text { SIC } \\
\text { code }^{1}\end{array}$} & \multicolumn{5}{|c|}{$\begin{array}{l}\text { Revised growth rate } \\
\text { (percent) }\end{array}$} & \multicolumn{5}{|c|}{$\begin{array}{l}\text { Difference between growth rates: } \\
\text { revised less earlier } \\
\text { (percentage points) }\end{array}$} \\
\hline & & 1994 & 1995 & 1996 & 1997 & 1998 & 1994 & 1995 & 1996 & 1997 & 1998 \\
\hline Total & $\cdots$ & 4.9 & -.8 & 1.5 & 1.0 & -2.6 & .2 & .3 & .5 & -.1 & .0 \\
\hline Manufacturing . & $\ldots$ & 5.1 & -.9 & 1.4 & 1.1 & -2.9 & .2 & .3 & .5 & .0 & .0 \\
\hline Durable manufacturing & & 3.4 & .5 & -.2 & 3.1 & -1.0 & .1 & .4 & .7 & -.5 & 1.1 \\
\hline Lumber and products & 24 & 2.9 & 1.5 & 4.3 & -.1 & 5.4 & .0 & -.6 & -.8 & -1.4 & -2.0 \\
\hline Furniture and fixtures & 25 & 7.6 & -3.6 & 4.2 & 1.4 & -1.4 & .4 & -.3 & -.1 & -.2 & .8 \\
\hline Stone, clay, and glass products & 32 & 2.1 & .2 & 3.4 & .8 & .6 & 6 & .4 & .4 & -.2 & .9 \\
\hline Primary metals...$\ldots \ldots \ldots$ & 33 & 3.0 & 1.5 & -3.8 & 4.0 & -1.2 & .0 & 1.4 & 2.3 & -.7 & 6 \\
\hline Fabricated metal products & 34 & 5.5 & .1 & 3.7 & 3.1 & -2.0 & .3 & .4 & .2 & -.2 & .4 \\
\hline Industrial machinery and equipment & 35 & 4.0 & .4 & 1.4 & 3.0 & 2.6 & .5 & .5 & -.2 & -.1 & 1.2 \\
\hline Electrical machinery.......... & 36 & 2.4 & 1.5 & 2.5 & 2.3 & 2.0 & .2 & -1.0 & -1.1 & -.8 & 5.1 \\
\hline Transportation equipment ... & 37 & 4.1 & -2.0 & -.3 & 5.2 & -7.5 & -.5 & -.8 & -.7 & -.4 & 1.1 \\
\hline Instruments ............... & 38 & 1.7 & .4 & -2.8 & .6 & 1.3 & .8 & .9 & .6 & -.3 & -.6 \\
\hline Miscellaneous manufactures . & 39 & 11.1 & -4.7 & 6.9 & .3 & -3.8 & -.2 & -1.1 & -1.4 & -.7 & .7 \\
\hline Nondurable manufacturing & & 6.5 & -2.0 & 2.6 & -.5 & -4.4 & .3 & .2 & .3 & .3 & -.9 \\
\hline Foods ................... & 20 & 4.5 & 2.5 & 1.7 & 2.2 & -.2 & 1.0 & .9 & .7 & .5 & -.7 \\
\hline Tobacco products & 21 & -5.5 & 6.3 & -.2 & .5 & -5.0 & -.3 & -1.2 & -2.2 & -2.3 & 3.2 \\
\hline Textile mill products & 22 & 6.0 & -3.4 & 2.9 & 2.1 & 2.6 & .6 & -.2 & .3 & -1.0 & -.9 \\
\hline Apparel products ...... & 23 & 6.8 & -6.4 & -1.8 & -2.0 & -8.5 & .5 & .4 & .8 & .5 & .3 \\
\hline Paper and products ...... & 26 & 2.7 & -.6 & .4 & 2.2 & -4.0 & -.1 & -.1 & .0 & 1.3 & .1 \\
\hline Printing and publishing . & 27 & 4.2 & .7 & .8 & 3.0 & -2.3 & .5 & .0 & .3 & -.4 & .8 \\
\hline Chemicals and products & 28 & 9.7 & -6.5 & 5.7 & -4.2 & -9.7 & .3 & .2 & .1 & -.1 & -2.2 \\
\hline Petroleum products $\ldots \ldots \ldots \ldots$ & 29 & 2.7 & 7.3 & -3.3 & 2.5 & -2.0 & .0 & 1.1 & 1.2 & 2.0 & 1.2 \\
\hline Rubber and plastics products . & 30 & 9.0 & -.5 & 3.4 & .6 & 3.7 & .3 & -.3 & -.2 & -.4 & -.1 \\
\hline Leather and products ........ & 31 & -3.5 & -9.2 & -1.4 & -1.7 & -8.0 & -.6 & .8 & -4.5 & -.6 & 1.4 \\
\hline Mining . & & 2.2 & 1.0 & 2.8 & -.4 & 1.8 & .0 & .0 & .5 & -1.2 & .6 \\
\hline Metal mining & 10 & 5.6 & 8.5 & 2.5 & .4 & .0 & -.2 & -.2 & -.1 & -.1 & -1.6 \\
\hline Coal mining . & 12 & 7.4 & -1.3 & .0 & -.6 & 8.1 & -.1 & .0 & .0 & .3 & 1.0 \\
\hline Oil and gas extraction & 13 & -4.8 & -4.9 & 4.4 & 1.0 & -4.5 & .0 & .0 & 1.4 & -.8 & -1.0 \\
\hline Stone and earth minerals & 14 & 7.5 & 5.7 & 3.7 & -4.2 & 10.5 & .2 & .5 & .2 & -5.8 & 7.3 \\
\hline \multicolumn{12}{|l|}{ Supplementary groups } \\
\hline Total, excluding nuclear nondefense & . & 3.7 & 6 & 9 & 2.2 & -1.5 & .2 & .3 & .4 & -.1 & .2 \\
\hline Utilities sales to industry $\ldots \ldots \ldots \ldots$ & . & 5.3 & -1.2 & 1.9 & 1.0 & -2.6 & .3 & .4 & .3 & .1 & .4 \\
\hline Industrial generation ..... & $\cdots$ & 1.3 & 4.8 & -5.7 & .8 & 2.4 & -.3 & -.1 & -.1 & .4 & 4 \\
\hline
\end{tabular}

Note. Growth rates are calculated as the percentage change in the seasonally 1. Standard Industrial Classification; see table A.4, note 1 . adjusted index from the fourth quarter of the previous year to the fourth quarter of the year specified. For 1998, the growth rates are calculated from the fourth quarter of 1997 to the third quarter of 1998 and annualized. 